\title{
Protein Kinase C Enhances Electrical Synaptic Transmission by Acting on Junctional and Postsynaptic $\mathrm{Ca}^{2+}$ Currents
}

\author{
(D)Christopher C. Beekharry, $P$ Yueling Gu, and Neil S. Magoski \\ Department of Biomedical and Molecular Sciences, Experimental Medicine Graduate Program, Queen's University, Kingston, Ontario K7L 3N6, Canada
}

By synchronizing neuronal activity, electrical transmission influences the coordination, pattern, and/or frequency of firing. In the hemaphroditic marine-snail, Aplysia calfornica, the neuroendocrine bag cell neurons use electrical synapses to synchronize a $30 \mathrm{~min}$ afterdischarge of action potentials for the release of reproductive hormone. During the afterdischarge, protein kinase C (PKC) is activated, although its impact on bag cell neuron electrical transmission is unknown. This was investigated here by monitoring electrical synapses between paired cultured bag cell neurons using dual whole-cell recording. Voltage clamp revealed a largely voltage-independent junctional current, which was enhanced by treating with a PKC activator, PMA, before recording. We also examined the transfer of presynaptic action potential-like waveforms (generated in voltage clamp) to the postsynaptic cell (measured in current clamp). For control pairs, the presynaptic spike-like waveforms mainly evoked electrotonic potentials; however, when PKC was triggered, these stimuli consistently produced postsynaptic action potentials. To assess whether this involved changes to postsynaptic responsiveness, single bag cell neurons were injected with junctional-like current mimicking that evoked by a presynaptic action potential. Unlike control neurons, which were less likely to spike, cells in PMA always fired action potentials to the junctional-like current. Furthermore, PKC activation increased a postsynaptic voltage-gated $\mathrm{Ca}^{2+}$ current, which was recruited even by modest depolarization associated with an electrotonic potential. Whereas PKC inhibits gap junctions in most systems, bag cell neurons are rather unique, as the kinase potentiates the electrical synapse; in turn, this synergizes with augmented postsynaptic $\mathrm{Ca}^{2+}$ current to promote synchronous firing.

Key words: action potential; afterdischarge; gap junction; junctional current; neuroendocrine cell; persistent $\mathrm{Ca}^{2+}$ current

\section{Significance Statement}

Electrical coupling is a fundamental form of communication. For the bag cell neurons of Aplysia, electrical synapses coordinate a prolonged burst of action potentials known as the afterdischarge. We looked at how protein kinase $\mathrm{C}$, which is upregulated with the afterdischarge, influences information transfer across the synapse. The kinase activation increased junctional current, a remarkable finding given that this enzyme is largely considered inhibitory for gap junctions. There was also an augmentation in the ability of a presynaptic neuron to provoke postsynaptic action potentials. This increased excitability was, in part, due to enhanced postsynaptic voltage-dependent $\mathrm{Ca}^{2+}$ current. Thus, protein kinase $\mathrm{C}$ improves the fidelity of electrotonic transmission and promotes synchronous firing by modulating both junctional and membrane conductances.

\section{Introduction}

Electrical synapses link the cytoplasm of neurons via paired hemichannels known as gap junctions (Söhl et al., 2005; McCracken

\footnotetext{
Received Sept. 12, 2017; revised Jan. 15, 2018; accepted Feb. 2, 2018.

Author contributions:Y.G. edited the paper; N.S.M. designed research; C.C.B. and Y.G. performed research;C.C.B., Y.G., and N.S.M. analyzed data; C.C.B. and N.S.M. wrote the paper.

This work was supported by a Natural Sciences and Engineer Research Council Discovery Grant to N.S.M. We thank Catherine A. London and Heather M. Hodgson for technical assistance; and Nadine M. Magoski for critical review of the paper.

The authors declare no competing financial interests.

Correspondence should be addressed to Dr. Neil S. Magoski, Department of Biomedical and Molecular Sciences, Queen's University, 4th Floor, Botterell Hall, 18 Stuart Street, Kingston, Ontario K7L 3N6, Canada. E-mail: magoski@queensu.ca.

DOI:10.1523/JNEUROSCI.2619-17.2018

Copyright $\odot 2018$ the authors $\quad 0270-6474 / 18 / 382796-13 \$ 15.00 / 0$
}

and Roberts, 2006). Because gap junctions permit the movement of intracellular solutes, particularly ionic current, electrical coupling promotes both synchronous action potential firing and feedforward excitation (Bennett, 2000; Bennett and Zukin, 2004). For example, inhibitory interneurons in rat neocortex achieve spike synchrony through electrical coupling (Galarreta and Hestrin, 1999; Gibson et al., 1999). Feedforward excitation, where presynaptic action potentials drive postsynaptic firing via an electrical synapse, is apparent in olfactory lobe periodic waves of the garden slug, Limax maximus (Ermentrout et al., 2004), as well as slow excitation of ink motor neurons in the sea snail, Aplysia californica (Carew and Kandel, 1977).

Electrical synapses also feature prominently in neuroendocrine cell networks, where synchronous recruitment leads to 
simultaneous bursting and collective hormone release into the bloodstream (Bosco et al., 2011; Magoski, 2017). Hence, by coordinating suprachiasmatic or hypothalamic neurons, electrical coupling plays a role in fundamental processes, such as circadian rhythms, lactation, parturition, and ovulation (Belin and Moos, 1986; Long et al., 2005; Ma et al., 2015). In Aplysia, ovulation is governed by a group of electrically coupled neuroendocrine cells called bag cell neurons (Conn and Kaczmarek, 1989; Zhang and Kaczmarek, 2008). Located in two clusters at the rostral end of the abdominal ganglion, bag cell neurons respond to brief cholinergic synaptic input with a synchronous 30 min burst of action potentials termed the afterdischarge (Kupfermann and Kandel, 1970; White and Magoski, 2012). During this burst, the neurons release egg-laying peptide hormone into the circulation, which brings about a series of behaviors leading to the deposition of fertilized eggs (Arch and Smock, 1977; Stuart et al., 1980; Michel and Wayne, 2002; Hickey et al., 2013).

The cholinergic input that evokes the afterdischarge causes relatively rapid action potentials from a resting membrane potential of $\sim-60 \mathrm{mV}$ (Kaczmarek et al., 1982; White and Magoski, 2012). Once the chemical synaptic input has ceased, the neurons depolarize to $\sim-40 \mathrm{mV}$ and fire a fast-phase of taller and slightly broader spikes at $\sim 5 \mathrm{~Hz}$ for $\sim 1 \mathrm{~min}$; subsequently, the rate falls to $\sim 1 \mathrm{~Hz}$ for $\sim 30 \mathrm{~min}$ during a slow phase, with action potential height and width increasing further (Kaczmarek et al., 1982; Sturgeon and Magoski, 2016). The afterdischarge represents the synchronous firing of all neurons, with simultaneous intracellular recordings always revealing cells spiking in unison (Kupfermann and Kandel, 1970; Blankenship and Haskins, 1979; Dargaei et al., 2014). Additionally, in vivo coupling can be recapitulated between pairs of bag cell neurons in vitro (Dargaei et al., 2014, 2015).

Once initiated, the afterdischarge is maintained by modulating various ion channels through second messengers and kinases (Conn and Kaczmarek, 1989; Zhang and Kaczmarek, 2008). This includes protein kinase $\mathrm{C}$ (PKC), which is triggered 1-2 min after onset, during the transition from fast to slow phase (Conn et al., 1989; Wayne et al., 1999). PKC causes the insertion of additional voltage-dependent $\mathrm{Ca}^{2+}$ channels into the membrane, which increases $\mathrm{Ca}^{2+}$ influx and boosts secretion (DeRiemer et al., 1985b; Strong et al., 1987; Zhang et al., 2008; Groten and Magoski, 2015). However, any role for PKC in regulating bag cell neuron gap junctions is unknown.

Here, we show that activating PKC enhances junctional current and electrical transmission between coupled cultured bag cell neurons; specifically, there is a greater propensity for presynaptic activity to cause postsynaptic spiking. We also find that PKC induces an increase in postsynaptic voltage-dependent $\mathrm{Ca}^{2+}$ current, which is recruited by electrotonic signaling to push the neuron past the firing threshold. Historically, PKC has been found to inhibit most gap junctions (for review, see Lampe and Lau, 2000, 2004; Pogoda et al., 2016); thus, our results provide a potentially novel instance of PKC augmenting junctional and membrane current to encourage feedforward excitation. This change in electrical transmission would ensure Aplysia reproduction by improving the spread and coordination of action potentials during the afterdischarge.

\section{Materials and Methods}

Animals and primary cell culture of Aplysia bag cell neurons. Adult A. californica (a hermaphrodite) weighing 150-500 g were obtained from Marinus and housed in an $\sim 300-1$ aquarium containing continuously circulating, aerated artificial sea water (Instant Ocean; Aquarium Systems) at $15^{\circ} \mathrm{C}$ on a $12 / 12 \mathrm{~h}$ light/dark cycle and fed Romaine lettuce 5 times a week. All experiments were approved by the Queen's University Animal Care Committee (protocol 1501 Magoski, 2013-041).

For primary cultures of isolated bag cell neurons, animals were anesthetized by an injection of isotonic $\mathrm{MgCl}_{2}$ ( $\sim 50 \%$ of body weight), the abdominal ganglion removed, and treated with neutral protease (13.33 $\mathrm{mg} / \mathrm{ml}$; 165859; Roche Diagnostics; RRID:SCR_001326) dissolved in tissue culture artificial sea water (tcASW; composition in mM as follows: $460 \mathrm{NaCl}, 10.4 \mathrm{KCl}, 11 \mathrm{CaCl}_{2} \cdot 2 \mathrm{H}_{2} \mathrm{O}, 55 \mathrm{MgCl}_{2} \cdot 6 \mathrm{H}_{2} \mathrm{O}, 15$ HEPES, $1 \mathrm{mg} / \mathrm{ml}$ glucose, $100 \mathrm{U} / \mathrm{ml}$ penicillin, and $0.1 \mathrm{mg} / \mathrm{ml}$ streptomycin, $\mathrm{pH}$ 7.8 , with $\mathrm{NaOH}$ ) for $18 \mathrm{~h}$ at $20^{\circ} \mathrm{C}-22^{\circ} \mathrm{C}$. The ganglion was then rinsed in fresh tcASW for $1 \mathrm{~h}$, after which the bag cell neuron clusters were dissected from their connective tissue. Using a fire-polished Pasteur pipette and gentle trituration, neurons were dispersed in tcASW onto $35 \times 10$ mm polystyrene tissue culture dishes (353001; Falcon/Fisher Scientific; RRID:SCR_008452). Neurons were maintained in a $14^{\circ} \mathrm{C}$ incubator and used within 1-3 d. Salts were from Fisher Scientific, ICN, or SigmaAldrich (RRID:SCR_008988).

Whole-cell, voltage- and current-clamp recording from bag cell neurons. Cells were viewed under phase contrast with a TS100-F inverted microscope (Nikon) equipped with a Nikon Plan Fluor $20 \times$ objective $(\mathrm{NA}=$ $0.5)$ or Plan Fluor extra-long working distance $40 \times$ objective $(\mathrm{NA}=$ 0.6). On occasion, photomicrographs $(1392 \times 1040$ pixels $)$ were acquired using a Pixelfly USB camera (Photon Technology) and the MicroManager 1.4.5 plugin (http://micro-manager.org; RRID:SCR_000415) for ImageJ 1.44n9 (http://rsbweb.nih.gov/ij/; RRID:SCR_003070) with $100-500 \mathrm{~ms}$ exposure times.

Membrane and junctional current and/or membrane potential were recorded using EPC-8 amplifiers (HEKA Electronics) and the tight-seal, whole-cell method (Hamill et al., 1981). Microelectrodes were pulled from 1.5-mm-external-diameter, 1.2-mm-internal-diameter borosilicate glass capillaries (TW150F-4; World Precision Instruments), and fire-polished to a resistance of $1-2 \mathrm{M} \Omega$ when filled with standard bag cell neuron intracellular saline (see below). Before seal formation, pipette junction potentials were nulled. After seal formation, the pipette capacitive current was cancelled and, following breakthrough, the whole-cell capacitive current was also cancelled, while the series resistance $(3-5 \mathrm{M} \Omega$ ) was compensated to $80 \%$ and monitored throughout the experiment. Current was filtered at $1 \mathrm{kHz}$ while voltage was filtered at $5 \mathrm{kHz}$ by the EPC- 8 built-in Bessel filter and sampled at $2 \mathrm{kHz}$ using an IBM-compatible personal computer, a Digidata 1322A analog-to-digital converter (Molecular Devices), and the Clampex acquisition program of pClamp software version 8.2 (Molecular Devices). Clampex was also used to control the membrane potential under voltage clamp and inject current in current clamp; in addition, neurons were manually set to -60 or $-40 \mathrm{mV}$ in current clamp by delivering constant bias current with the EPC-8 $\mathrm{V}$-hold. Data were gathered at room temperature $\left(20^{\circ} \mathrm{C}-22^{\circ} \mathrm{C}\right)$.

Most recordings were made with normal artificial seawater (nASW; composition as per tcASW but lacking glucose and antibiotics) in the bath, while the pipette was filled with standard intracellular saline (composition in mM as follows: $500 \mathrm{~K}^{+}$-aspartate, $70 \mathrm{KCl}, 1.25 \mathrm{MgCl}_{2} \cdot 6 \mathrm{H}_{2} \mathrm{O}$, 10 HEPES, 11 glucose, 10 reduced glutathione, 5 EGTA, 5 adenosine 5 '-triphosphate $2 \mathrm{Na} \cdot \mathrm{H}_{2} \mathrm{O}$ [A3377; Sigma-Aldrich], and 0.1 guanosine $5^{\prime}$-triphosphate $\mathrm{Na} \cdot \mathrm{H}_{2} \mathrm{O}$ [G8877; Sigma-Aldrich], pH 7.3 with $\mathrm{KOH}$ ). Based on a calculation using WebMaxC (http://web.stanford.edu/ $\sim$ cpatton/webmaxcS.htm; RRID:SCR_003165), $3.75 \mathrm{~mm} \mathrm{CaCl}_{2}$ was added to the intracellular saline to set the free $\mathrm{Ca}^{2+}$ at $300 \mathrm{nM}$, which corresponds to bag cell neuron resting intracellular $\mathrm{Ca}^{2+}$ as found in prior studies (Loechner et al., 1992; Fisher et al., 1994; Magoski et al., 2000). A junction potential of $15 \mathrm{mV}$ was calculated for intracellular saline versus nASW and compensated for by subtraction off-line.

In one set of experiments, voltage-gated $\mathrm{Ca}^{2+}$ current was recorded in single cells. For these cases, the bath contained $\mathrm{Ca}^{2+}-\mathrm{Cs}^{+}$-tetraethylammonium (TEA) ASW, where the $\mathrm{K}^{+}$and $\mathrm{Na}^{+}$were replaced with $\mathrm{Cs}^{+}$and TEA, respectively, with a composition (in mM) as follows: 460 TEA-Cl, $10.4 \mathrm{CsCl}, 11 \mathrm{CaCl}_{2} \cdot 2 \mathrm{H}_{2} \mathrm{O}, 55 \mathrm{MgCl}_{2} \cdot 6 \mathrm{H}_{2} \mathrm{O}, 15 \mathrm{HEPES}, \mathrm{pH}$ 7.8 with $\mathrm{CsOH}$. The pipette was filled with a $\mathrm{Cs}^{+}$-Asp-based intracellular (composition in mM as follows: $70 \mathrm{CsCl}, 10 \mathrm{HEPES}, 11$ glucose, 10 glutathione, $1.25 \mathrm{MgCl}_{2} \cdot 6 \mathrm{H}_{2} \mathrm{O}, 5$ EGTA, 500 aspartic acid; 5 adenosine 5 '-triphosphate $2 \mathrm{Na} \cdot \mathrm{H}_{2} \mathrm{O}$, and 0.1 guanosine $5^{\prime}$-triphosphate $\mathrm{Na} \cdot \mathrm{H}_{2} \mathrm{O}, \mathrm{pH}$ 

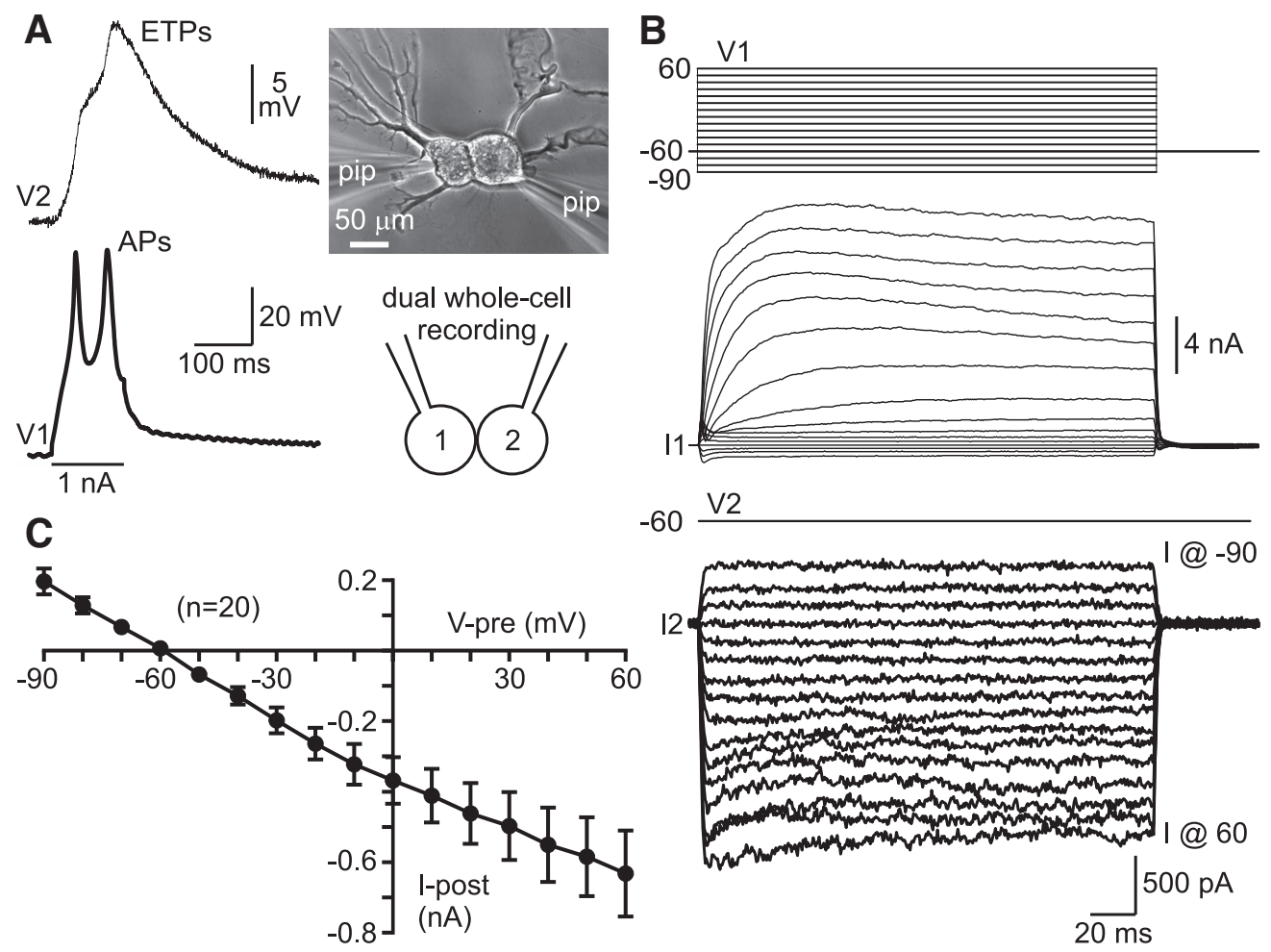

Figure 1. Bag cell neurons are electrically coupled in culture and show a voltage-independent junctional current. $A$, Two electrically coupled cultured bag cell neurons under dual whole-cell current clamp using our standard $\mathrm{K}^{+}$-Asp-based intracellular saline in the pipettes and nASW in the bath. A $1 \mathrm{nA}$ depolarizing current injection into neuron 1 evokes action potentials (APs) (V1; bottom), resulting in ETPs in neuron 2 (V2; top). Time-base applies to both traces. Top inset, Phase-contrast photomicrograph of paired bag cell neurons in soma-soma configuration after $2 \mathrm{~d}$ in culture. Large processes are visible in the upper FOV. The whole-cell pipettes (pip) are slightly of focus in the lower FOV. Bottom inset, Recording configuration with both cells in whole-cell mode. B, Dual whole-cell voltage clamp of coupled bag cell neurons also using $\mathrm{K}^{+}$-Asp-based intracellular saline and nASW. Both neurons are held at $-60 \mathrm{mV}$, and neuron 1 is stepped from -90 to 60 $\mathrm{mV}$ in $200 \mathrm{~ms}, 10 \mathrm{mV}$ intervals (V1; top). This evokes voltage-dependent membrane current in neuron 1 (11; top-middle) and junctional current in neuron 2 (I2; bottom). Time-base applies to all panels. C, Plotting the average end-pulse current from neuron 2 as postsynaptic or junctional current (I-post) against the presynaptic voltage of neuron 1 (V-pre) shows a mainly linear, voltageindependent relationship. That stated, there is some modest reduction of the inward current at presynaptic voltages more positive than $0 \mathrm{mV}$. $N$ value refers to number of pairs.

7.3 with $\mathrm{CsOH}$ ). A junction potential of $20 \mathrm{mV}$ was calculated for this intracellular saline versus $\mathrm{Ca}^{2+}-\mathrm{Cs}^{+}$-TEA ASW and again compensated for by subtraction off-line.

Drug application and other reagents. Solution changes were accomplished using a calibrated transfer pipette to exchange the bath (tissue culture dish) solution. Drugs were introduced by initially removing a small volume $(\sim 50 \mu \mathrm{l})$ of saline from the bath, combining that with an even smaller volume $(<10 \mu \mathrm{l})$ of drug stock solution, then reintroducing that mixture back into the bath. Care was taken to pipette near the side of the dish and as far away as possible from the cells. Niflumic acid (NFA; N0630; Sigma-Aldrich), 5-nitro-2-(3-phenylpropylamino) benzoic acid (NPPB; N4779; Sigma-Aldrich), 4- $\alpha$-phorbol (P4888; Sigma-Aldrich), and PMA (P8139; Sigma-Aldrich) were dissolved as stocks of $100 \mathrm{~mm}$, $50 \mathrm{~mm}, 100 \mu \mathrm{M}$, and $100 \mu \mathrm{M}$, respectively, in DMSO (BP231-1; Fisher Scientific). The maximal final concentration of DMSO ranged from $0.05 \%$ to $0.5 \%(\mathrm{v} / \mathrm{v})$, which in control experiments here and in previous work had no effect on holding current, membrane conductance, or junctional current (Hung and Magoski, 2007; Geiger and Magoski, 2008; Tam et al., 2009, 2011; Hickey et al., 2010; Dargaei et al., 2014, 2015; Groten and Magoski, 2015; Sturgeon and Magoski, 2016). For PMA, neuronal pairs or individual neurons were incubated in the drug for 20-30 min before establishing whole-cell recording.

Analysis. Most analysis involved pairs of bag cell neurons designated as neuron 1 and neuron 2, with membrane potentials and membrane currents specified as V1, V2, I1, and I2, respectively. The Clampfit (version 8.1 or 10.2) analysis program of pCLAMP was used to determine the amplitude of changes to membrane current or voltage. For changes in current, a pair of cursors, 5-20 ms apart, was placed $1 \mathrm{~ms}$ before the response evoked by a given voltage step, and the mean current between these two cursors taken as baseline. If the current change was measured at steady state, another pair of cursors was placed at 170 and $190 \mathrm{~ms}$ of the response to a $200 \mathrm{~ms}$ step (for details, see Results), and the mean current measured between these two cursors. The steady-state mean was compared with baseline mean and taken as the amplitude. If the current change was measured at peak, a cursor was placed 1-5 ms after the onset of the response, while another cursor was placed where the current had returned to near baseline. The peak current change between these two cursors, relative to the preresponse baseline cursors (see above), was then calculated.

For changes in voltage, a pair of cursors, also 5-20 ms apart, was placed $1 \mathrm{~ms}$ before the estimated inflection point of the response (electrotonic potential [ETP] or action potential), and the mean voltage between these two cursors taken as baseline. In addition, a cursor was placed $1-5 \mathrm{~ms}$ after the inflection point of the voltage change, while another cursor was placed where the voltage had returned to baseline. The peak voltage change between these two cursors, relative to the baseline, was then calculated. Action potential area was measured by placing a cursor in front of the spike (as per above) and another at the steady-state voltage after the spike. The difference between the two cursors was taken as the region of the action potential, above which the area was calculated. In cases where a gap junction blocker was applied (for details, see Results), junctional current or ETP amplitude was measured both immediately before the drug was delivered to the bath and 10 min later.

Junctional or membrane current was plotted against test voltage using Prism version 6.0 (GraphPad Software; RRID:SCR_002798). Bar graphs of junctional or membrane current, ETP amplitude, as well as the action potential occurrence, height, and area were also constructed in Prism. Statistics were performed using InStat version 3.1 (GraphPad). Data are mean \pm SEM. The Kolmogorov-Smirnov method was used to test datasets for normality. For normality distributed data, Student's paired or unpaired $t$ test, with Welch correction as necessary, was used to test for 
A input stimulus
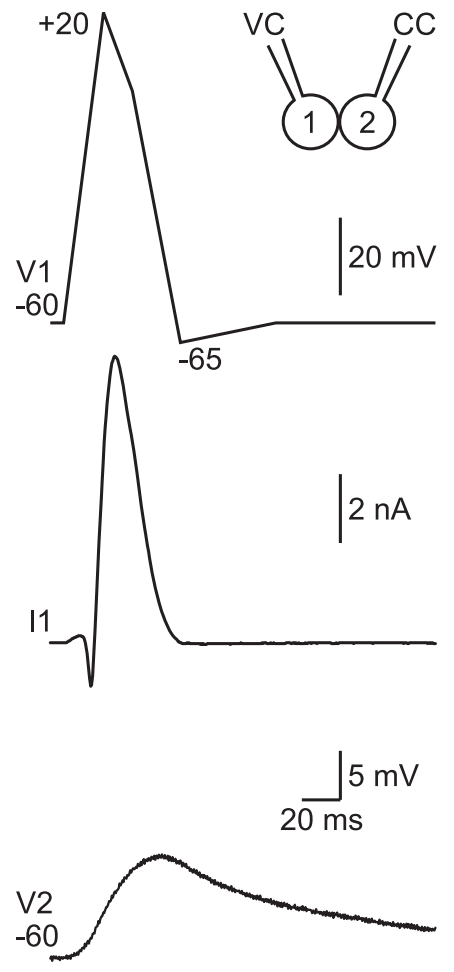

B fast-phase stimulus
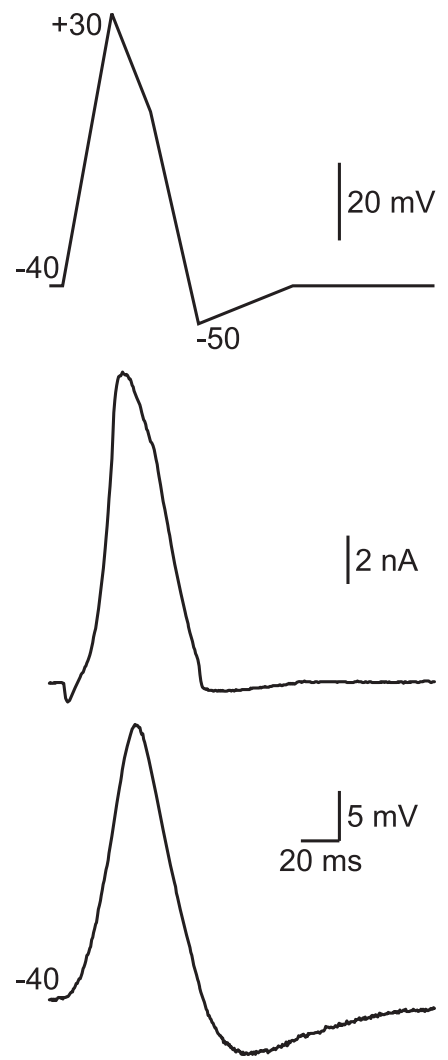

C slow-phase stimulus
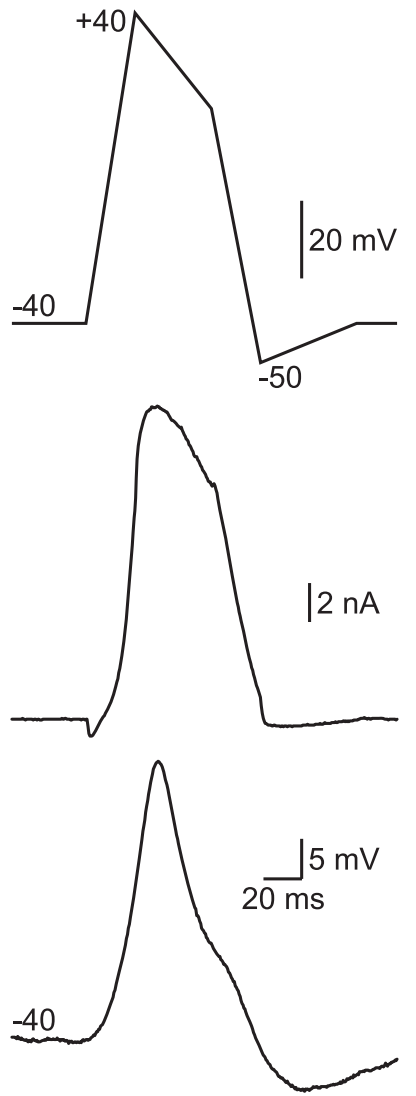

Figure 2. Presynaptic stimulation with action potential-like waveforms shows electrotonic transmission between coupled bag cell neurons. With neuron 1 voltage-clamped and neuron 2 current-clamped in a pair of electrically coupled bag cell neurons in vitro (inset), delivery of action potential-like waveforms from specific phases of the afterdischarge (to neuron 1 ) evokes electronic responses in the coupled partner (neuron 2). A, A spike-like waveform delivered from $-60 \mathrm{mV}$ under voltage clamp, mimicking the input stimulus of the afterdischarge (V1; top), elicits an action current in neuron 1 (I1; middle) and evokes an ETP in neuron 2, which is first set to $-60 \mathrm{mV}$ under current clamp with bias current (V2; bottom). The action current initially presents rapid inward current $\left(\mathrm{Ca}^{2+}\right.$ and $\mathrm{Na}^{+}$current), which is quickly obscured by the large outward $\mathrm{K}^{+}$current. $\boldsymbol{B}, \boldsymbol{C}$, Waveforms corresponding to the action potential during the fast phase (B) or slow phase $(\boldsymbol{C})$ of the afterdischarge, both from a holding potential of $-40 \mathrm{mV}$, again evoke action currents in neuron 1 as well as produce ETPs (essentially spikelets) in neuron 2 , which is also originally set to - 40 $\mathrm{mV}$. The slow-phase ETP is slightly broader. $\boldsymbol{A}$-C, Time-base applies to the top, middle, and bottom.

differences between two means. A repeated-measures ANOVA, followed by a test for linear trend, was used to examine an increasing or decreasing change in group data. For data that were not normally distributed, a Mann-Whitney $U$ test was used to test for differences between two means. Differences in action potential occurrence were tested using Fisher's exact test. An outcome was considered statistically different if the two-tailed $p$ value was $<0.05$.

\section{Results}

Pairs of cultured bag cell neurons are electrically coupled and show a voltage-independent junctional current

In vivo, bag cell neurons are electrically coupled to multiple partners, making it difficult to rigorously investigate gap junctionbased communication (Blankenship and Haskins, 1979; Haskins and Blankenship, 1979; Dargaei et al., 2014). Thus, to assay electrical synapses in a more restricted setting, bag cell neurons were dissociated and plated in close proximity to each other as pairs (for details, see Animals and primary cell culture of Aplysia bag cell neurons). Consistent with our prior work in this regard (Dargaei et al., 2014), after 2-3 d in vitro, pairs formed a neurite-neurite, neuritesoma, or soma-soma electrical synapse, the latter being the most common (Fig. 1A, top inset). Whole-cell recording in either voltage- or current-clamp mode was used; and with one exception (for details, see Bag cell neuron voltage-gated $\mathrm{Ca}^{2+}$ current is enhanced by PKC activation), measurements were made with
nASW in the bath and our standard $\mathrm{K}^{+}$-Asp-based intracellular saline in the recording pipettes (for details, see Whole-cell, voltage- and current-clamp recording from bag cell neurons). Neurons were identified as neuron 1 and neuron 2, with the protocols run using neuron 1 as presynaptic (receiving test potentials or current pulses) and neuron 2 as postsynaptic (reporting the junctional current or the effect of junctional current on membrane voltage).

To demonstrate the presence of an electrical synapse, a $1 \mathrm{nA}$, $125 \mathrm{~ms}$ depolarizing current was injected into neuron 1 under current clamp while also monitoring the membrane potential of neuron 2 (Fig. 1A, bottom inset). This elicited action potential firing in neuron 1 , which in turn generated ETPs in neuron 2 (Fig. $1 A)$. Junctional current was measured under voltage clamp by applying a test potential to neuron 1 and measuring the current in neuron 2 (Bennett, 1966). With both neurons initially held at $-60 \mathrm{mV}$, neuron 1 was stepped through a series of $10 \mathrm{mV}, 200 \mathrm{~ms}$ steps from -90 to $60 \mathrm{mV}$, while maintaining neuron 2 at $-60 \mathrm{mV}$ ( $n=20$ pairs) (Fig. $1 B$, top and bottom middle). In response, the presynaptic neuron 1 displayed membrane current that was outwardly rectifying at potentials more positive than $-30 \mathrm{mV}$, which in all likelihood consisted largely of voltage-gated $\mathrm{K}^{+}$current (Kaczmarek and Strumwasser, 1984) (Fig. 1B, top-middle). By contrast, the postsynaptic neuron 2 presented a current with a 

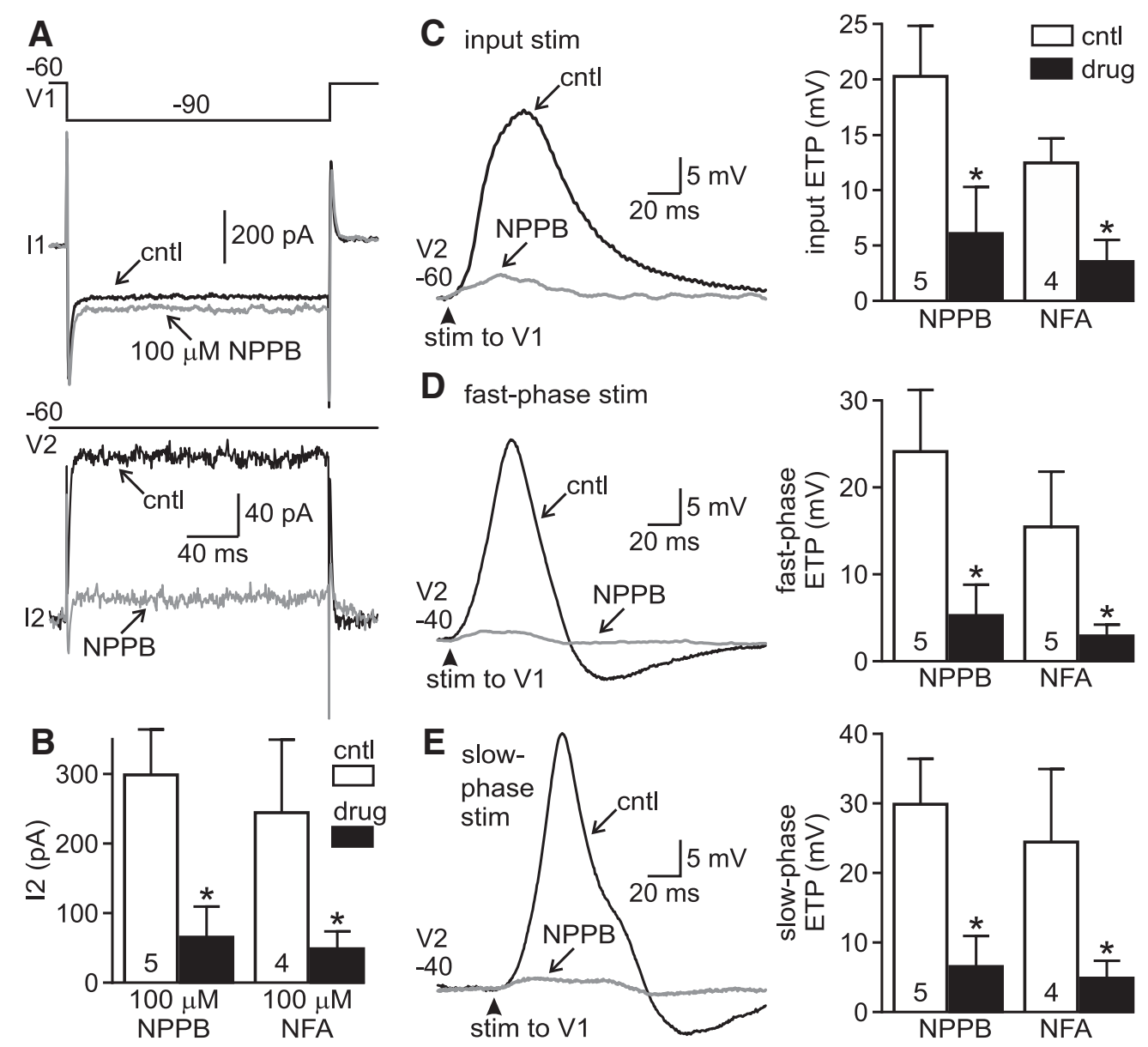

Figure 3. Pharmacological block of junctional current and voltage transfer between coupled bag cell neurons. $A$, In an electrically coupled cultured pair, both bag cell neurons are held at $-60 \mathrm{mV}$ (top and bottom middle) under whole-cell voltage clamp. A $200 \mathrm{~ms}$ pulse to $-90 \mathrm{mV}$ in neuron 1 evokes membrane current in neuron 1 (I1; black trace, top-middle) and junctional current in neuron 2 (I2; black trace, bottom). Bath application of $100 \mu \mathrm{m} \mathrm{NPPB} \mathrm{to} \mathrm{the} \mathrm{same} \mathrm{pair} \mathrm{of} \mathrm{neurons} \mathrm{for} 10$ min markedly inhibits junctional but not membrane current (gray traces, top and bottom). Time-base applies to all traces. $B$, Summary graph show that both NPPB and NFA (100 $\mu \mathrm{m}$ ) significantly reduce the end-pulse junctional current (NPPB, $t_{(4)}=2.077,{ }^{*} p<0.04, \mathrm{NFA}, t_{(4)}=5.317,{ }^{*} p<0.007$; both paired Student's $t$ test). Numbers in white columns are $n$ values and indicate the number of pairs recorded before and after exposure to drug. $(-\boldsymbol{E}$, Left, While voltage clamping neuron 1 and current-clamping neuron 2, delivering the input-phase $(\boldsymbol{C}$ ), fast-phase $(\boldsymbol{D})$, or slow-phase $(\boldsymbol{E})$ stimulus (stim; at arrowhead) to neuron 1 elicits an ETP in neuron 2 (black traces). In all cases, the subsequent addition of $100 \mu \mathrm{m} \mathrm{NPPB} \mathrm{largely} \mathrm{eliminates} \mathrm{the} \mathrm{ETP} \mathrm{(gray} \mathrm{traces).} \mathrm{D,} \mathrm{E,} \mathrm{Control} \mathrm{traces} \mathrm{reproduced} \mathrm{from} \mathrm{Figure} \mathrm{2.} \mathrm{Right,} \mathrm{Summary} \mathrm{graphs} \mathrm{show} \mathrm{that} \mathrm{both} \mathrm{NPPB} \mathrm{and} \mathrm{NFA} \mathrm{significantly} \mathrm{lower}$ the peak response of all three types of ETP (NPPB input-phase, $t_{(4)}=3.277,{ }^{*} p<0.02$; NPPB fast-phase, $t_{(4)}=2.576,{ }^{*} p<0.04$; NPPB slow-phase, $t_{(4)}=3.544,{ }^{*} p<0.02 ;$ NFA input-phase, $t_{(3)}=2.224,{ }^{*} p<0.03$; NFA fast-phase, $t_{(4)}=2.379,{ }^{*} p<0.04$; NFA slow-phase, $t_{(4)}=2.385,{ }^{*} p<0.05$; all paired Student's $t$ test). The $n$ values indicate the number of pairs recorded before and after exposure to drug.

very rapid onset that was essentially proportional to the test potential magnitude (Fig. 1B, bottom). This corresponds to the current passed by the voltage clamp necessary to keep neuron 2 at $-60 \mathrm{mV}$, and thus represents the junctional current flowing across the electrical synapse. Plotting the mean steady-state postsynaptic current (junctional current) versus the presynaptic test potential revealed a linear relationship between -90 and $-10 \mathrm{mV}$ (Fig. 1C). That stated, starting at $0 \mathrm{mV}$ and continuing through to $60 \mathrm{mV}$, there was a slight voltage-dependent reduction in junctional current.

\section{Action potential-like waveforms are electrically transmitted from voltage-clamped presynaptic to current-clamped postsynaptic coupled bag cell neurons}

During the afterdischarge, changes to electrical transmission are likely context specific, with respect to both the shape of the action potential at different phases and what second messengers or effectors, such as PKC, are activated. Thus, rather than simply driving presynaptic spikes and recording the postsynaptic response, action potential-like waveforms were delivered to neuron 1 under voltage clamp, and the resulting change in the membrane potential of neuron 2 was measured under current clamp. By controlling presynaptic voltage, the influence of kinases or blockers on the transfer of electrical information can be directly evaluated, allowing for differentiating between modulation of junctional versus presynaptic or postsynaptic membrane conductance. Moreover, any changes to presynaptic threshold or excitability, including how the presynaptic neuron responds to depolarizing current injection before and during an action potential, can be prevented from confounding the assay.

Action potential-like waveforms that correspond to the different phases of the afterdischarge were constructed based on spikes from genuine afterdischarges recorded in the intact cluster under current clamp by White and Magoski (2012), Dargaei et al. (2014), and Sturgeon and Magoski (2016). Specifically, we constructed waveforms to match the action potentials elicited by chemical synaptic input from resting potential $(\sim-60 \mathrm{mV})$ when an afterdischarge is being stimulated (termed here as the input phase), as well as the spikes that occur from a depolarized state $(\sim-40 \mathrm{mV})$ during the fast phase and slow phase of the afterdischarge itself 
(Kaczmarek et al., 1982) (for details, see Introduction). Neuron 1 received either an input-phase action potential-like waveform from $-60 \mathrm{mV}$ (Fig. $2 A$, top) or a fast- or slow-phase action potential-like waveform from $-40 \mathrm{mV}$ (Fig. $2 B, C$, top). The input-phase spike-like waveform was a ramp from -60 to $20 \mathrm{mV}$ in $20 \mathrm{~ms}$, then a ramp to $0 \mathrm{mV}$ in $15 \mathrm{~ms}$, followed by another ramp to $-65 \mathrm{mV}$ in $25 \mathrm{~ms}$, and finally a ramp back to $-60 \mathrm{mV}$ in $50 \mathrm{~ms}$. The fast- and slow-phase spike-like waveform were ramps from -40 to $30 \mathrm{mV}$ (fast) or $40 \mathrm{mV}$ (slow) in $25 \mathrm{~ms}$, then a ramp to $5 \mathrm{mV}$ in $20 \mathrm{~ms}$ (fast) or to 15 in $40 \mathrm{~ms}$ (slow), followed by an additional ramp to $-50 \mathrm{mV}$ in $25 \mathrm{~ms}$, and last a ramp back to $-40 \mathrm{mV}$ in $50 \mathrm{~ms}$. In each instance, before delivery of the presynaptic waveform, neuron 2 was initially set to the appropriate membrane potential $(-60$ or $-40 \mathrm{mV})$ in current clamp using bias current. Each stimulus evoked a corresponding action current in neuron 1 (Fig. $2 A-C$, middle) and a postsynaptic ETP in neuron 2. The input stimulus elicited a slow ETP (Fig. $2 A$, bottom), whereas both the fast- and slow-phase stimuli generated an ETP that often more closely followed the presynaptic waveform (Fig. $2 B, C$, bottom).

\section{Gap junction blockers attenuate junctional current and electrical transmission between bag cell neurons}

Gap junctions can be blocked by a variety of compounds, including some arylaminobenzoates (Harks et al., 2001; Srinivas and Spray, 2003). To be certain that the transmission observed under the voltage-clamp/current-clamp configuration was electrical, gap junction blockers previously established as effective on junctional current between coupled bag cell neurons were used, specifically, NPPB and NFA (Dargaei et al., 2014). Initially, the ability of these reagents to inhibit junctional current was confirmed under voltage clamp, where both neurons were held at $-60 \mathrm{mV}$ and the voltage in neuron 1 was stepped to $-90 \mathrm{mV}$ for $200 \mathrm{~ms}$ while maintaining neuron 2 at $-60 \mathrm{mV}$ (Fig. $3 A$, top and bottom middle). The resulting junctional current in neuron 2 was measured at steady state before and $10 \mathrm{~min}$ after introducing $100 \mu \mathrm{M}$ of either NPPB $(n=5)$ or NFA $(n=4)$. The junctional current was clearly diminished (Fig. $3 A$, bottom), whereas the membrane current in neuron 1 was minimally altered (Fig. $3 A$, top-middle). On average, the reduction in junctional current with NPPB or NFA was $\sim 75 \%$ and found to be significant (Fig. $3 B$ ).

Next, the impact of gap junction blockers was evaluated under presynaptic voltage clamp and postsynaptic current clamp. Neuron 1 received either the input- (Fig. 3C, left), fast- (Fig. 3D, left), or slow-phase (Fig. 3E, left) action potential-like waveform, and the voltage transfer to neuron 2 was monitored. In control, postsynaptic ETPs were generated in response to all three presynaptic stimuli; however, after delivery of $100 \mu \mathrm{M}$ of either NPPB $(n=5)$ or NFA ( $n=4$ input, slow; $n=5$ fast), the electrical transmission was markedly lowered. The outcome of comparing the group data before and after NPPB or NFA was a significant, $70 \%-80 \%$ decrease in the ETP evoked by all three waveforms (Fig. 3C-E, right).

\section{PKC activation enhances junctional current}

Shortly after the onset of the afterdischarge, PKC activity is elevated and stays as such for the duration of the burst (Conn et al., 1989; Wayne et al., 1999). PKC has been shown to phosphorylate connexin proteins and alter electrical coupling in different cells (Enomoto et al., 1981; Sáez et al., 1990; Spray and Burt, 1990; Lampe et al., 2000). Here, we tested the effect of the phorbol ester, PMA, a PKC activator that is well established as effective in whole Aplysia nervous tissue and bag cell neurons (Castagna et al., 1982; DeRiemer et al., 1985a; Azhderian and Kaczmarek, 1991; Sossin
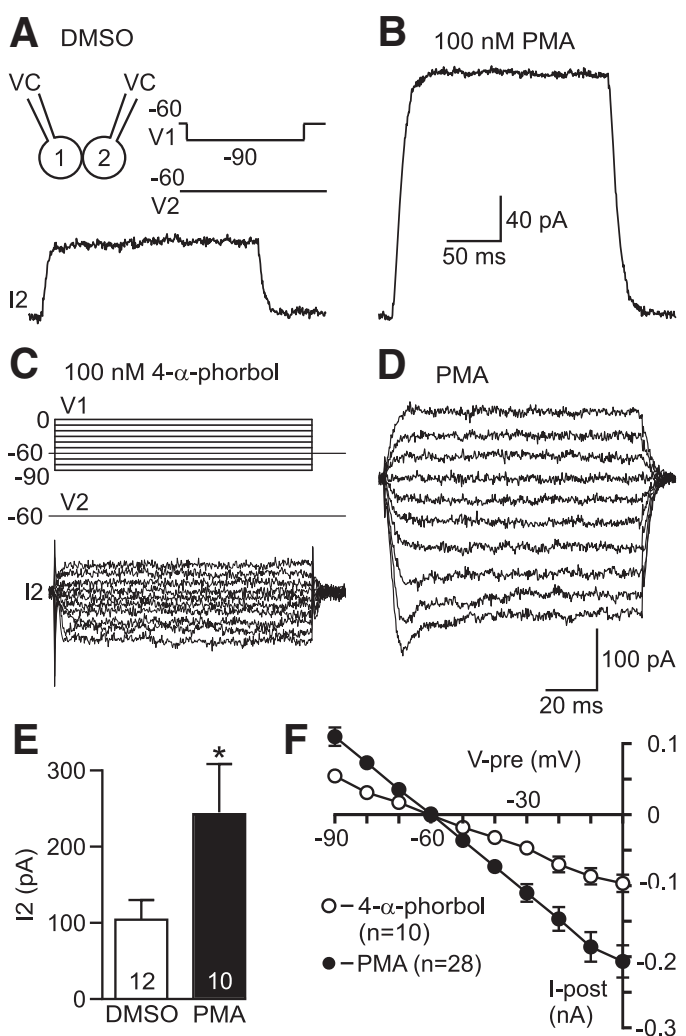

Figure 4. PKC activation increases junctional current between coupled bag cell neurons. $A$, Following a 20 min treatment with DMSO, both bag cell neurons in a cultured pair are held at $-60 \mathrm{mV}$ under voltage clamp (left inset). When a pulse to $-90 \mathrm{mV}$ is given to neuron 1 (right inset), it evokes a junctional current (I2) in neuron 2. B, In a different pair, exposed to $100 \mathrm{~nm}$ of the PKC activator, PMA for 20 min before recording, the junctional current is more than double that of control. Scale bars apply to both $\boldsymbol{A}$ and $\boldsymbol{B}$. $\boldsymbol{C}$, Neurons from another pair, previously exposed for $20 \mathrm{~min}$ to $100 \mathrm{~nm}$ of the inactive PMA-analog, 4- $\alpha$-phorbol, are voltage clamped at $-60 \mathrm{mV}$. Stepping neuron 1 from -90 to $0 \mathrm{mV}$ in $200 \mathrm{~ms}, 10 \mathrm{mV}$ intervals (V1; top), whereas keeping neuron 2 at $-60 \mathrm{mV}$ (V2; middle) results in range of small junctional currents (I2; bottom). $\boldsymbol{D}$, When the same voltage-step protocol as per $\boldsymbol{C}$ is delivered to a bag cell neuron pair that has been treated with PMA for 20 min, the junctional current is larger at all test voltages. Scale bars apply to both $\boldsymbol{C}$ and $\boldsymbol{D}$. $\boldsymbol{E}$, Group data show that, compared with electrically coupled cells given the vehicle, DMSO, providing PMA significantly enhances the junctional current elicited by a presynaptic step to $-90 \mathrm{mV}\left(U=22.0,{ }^{*} p<0.02\right.$; Mann-Whitney $U$ test). $N$ values indicate number of pairs recorded following DMSO or PMA treatment. $F, A$ summary plot of neuron 2 end-pulse current (I-post) versus the test potential in neuron 1 (V-pre) reveals that the junctional current produced by each presynaptic step is clearly greater for pairs incubated in PMA (close circles) compared with the inactive analog, 4- $\alpha$-phorbol (open circles). At all given test potentials, the difference between the junctional currents is significant $\left(-90 \mathrm{mV}, t_{(35)}=\right.$ $3.673, p<0.001 ;-80 \mathrm{mV}, t_{(35)}=4.297, p<0.0002 ;-70 \mathrm{mV}, t_{(35)}=3.596, p<0.002$; $-50 \mathrm{mV}, t_{(35)}=3.609, p<0.0002 ;-40 \mathrm{mV}, t_{(35)}=4.383, p<0.0002 ;-30 \mathrm{mV}, t_{(35)}=$ $4.392, p<0.0002 ;-20 \mathrm{mV}, t_{(35)}=3.834, p<0.0006 ;-10 \mathrm{mV}, t_{(35)}=4.174, p<0.0003$; $0 \mathrm{mV}, t_{(35)}=4.258, p<0.0002$; all Student's $t$ test with Welch correction). Consequently, the slope is more than two-fold greater when PKC is activated. $N$ values indicate number of pairs recorded subsequent to 4 - $\alpha$-phorbol or PMA treatment.

et al., 1993). For junctional current, neuronal pairs were initially treated with DMSO (the vehicle) or $100 \mathrm{nM}$ PMA for 20-30 min, and then voltage-clamped at $-60 \mathrm{mV}$ (Fig. $4 A$, inset). Subsequent to establishing whole-cell mode, neuron 1 was then pulsed to $-90 \mathrm{mV}$ to evoke a junctional current in neuron 2. Compared with DMSO $(n=12)$, the current was more than two-fold greater with PMA $(n=10)$ (Fig. $4 A, B)$; the summary data showed this difference to be significant (Fig. $4 E$ ).

To control for any off-target effects of PMA, we also used 4- $\alpha$-phorbol, an inactive PMA analog that has been found to be ineffective at turning on Aplysia PKC in both biochemical and 


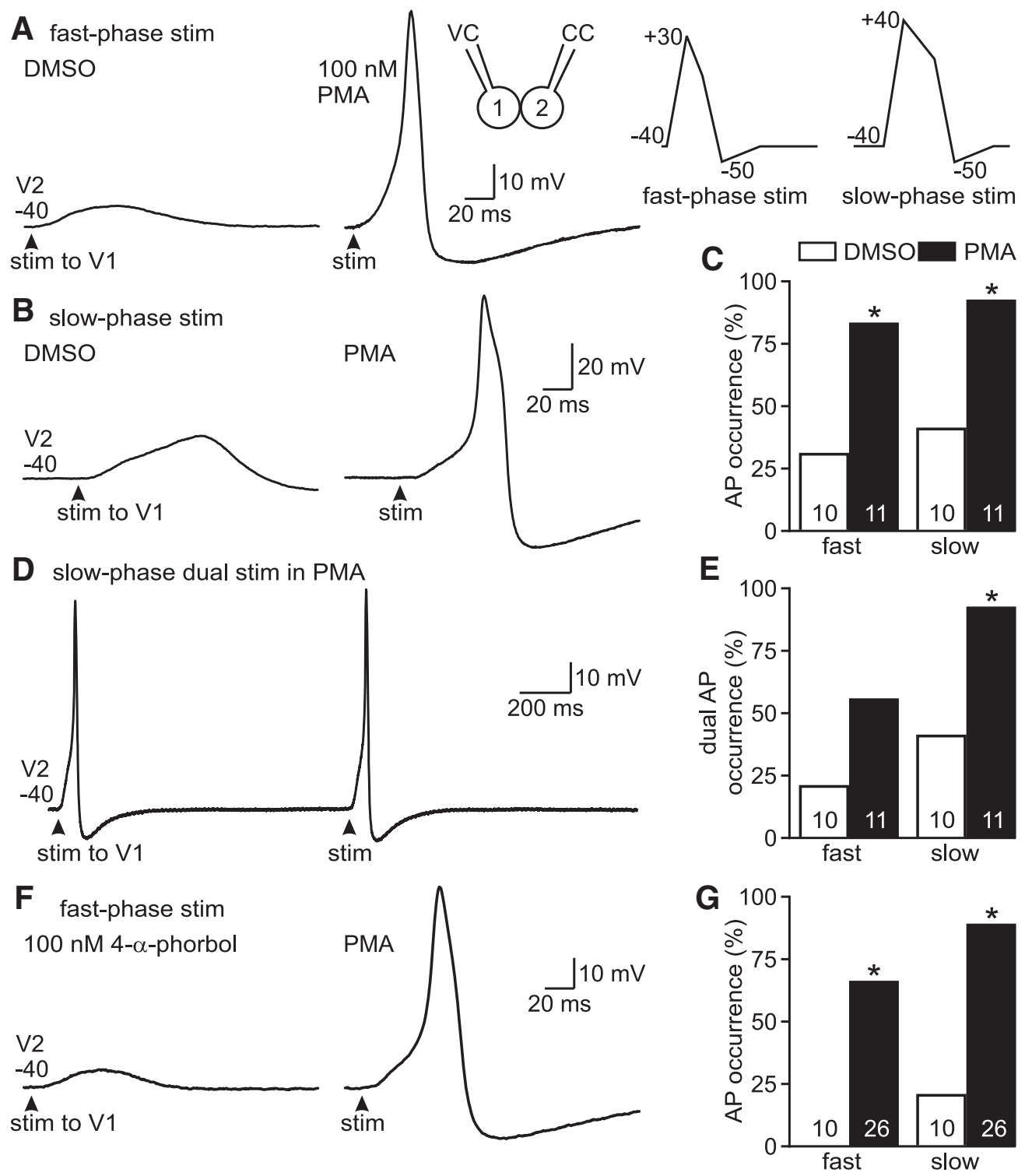

Figure 5. Activating PKC modulates electrical transmission between coupled bag cell neurons. $A$, After treating pairs of cultured bag cell neurons for $20-30$ min with either DMSO or $100 \mathrm{~nm}$ PMA, neuron 1 is voltage-clamped at $-40 \mathrm{mV}$ and neuron 2 is current-clamped such that the membrane potential is initially set to $-40 \mathrm{mV}$ (left inset). Left, For DMSO, a fast-phase stimulus to neuron 1 (stim, at arrowhead; middle inset) typically evokes an ETP in neuron 2 (V2). Right, For a pair where PKC is activated by PMA, the most common response is a postsynaptic action potential in neuron 2 following a fast-phase stimulus to neuron 1 . Scale bars apply to both traces. B, Similarly, delivering the slow-phase stimulus (right inset) to neuron 1 elicits an action potential in neuron 2 for pairs treated with PMA (right) but not DMSO (left). Scale bars apply to both traces. C, Group data reveal that PKC activation leads to a greater probability of postsynaptic spiking. Following a single fastor slow-phase presynaptic stimulus, the frequency of action potential occurrence is significantly greater in pairs treated with PMA compared with DMSO (fast-phase RR $=3.85$, ${ }^{*} p=0.03$; slow-phase $R R=6.6,{ }^{*} p<0.03$; both Fisher's exact test). $\boldsymbol{D}$, When neuron 1 receives dual slow-phase stimuli at $1 \mathrm{~Hz}$, the presence of PMA results in neuron 2 firing a spike in response to both stimuli. $\boldsymbol{E}$, Group data also show how PMA renders it significantly more likely that dual presynaptic slow-phase action potential-like waveforms, given at $1 \mathrm{~Hz}$, produce two spikes in neuron 2 (RR $=6.6$, ${ }^{*} p<0.03$; Fisher's exact test); however, this is not the case for dual fast-phase waveforms given at $5 \mathrm{~Hz}$ (RR $=1.76, p>0.05$; Fisher's exact test). $N$ values indicate number of pairs recorded following DMSO or PMA treatment. $F$, Left, When a pair is incubated for 20 min in $100 \mathrm{~nm} 4-\alpha$-phorbol, and neuron 1 is given the same fast-phase stimulus as per $A$, the response in neuron 2 (V2) is always an ETP. Right, However, if neurons are treated with PMA, the majority of cases see an action potential being brought about in neuron 2 . Scale bars apply to both traces. $\mathbf{G}$, Group data establish that, compared with 4- $\alpha$-phorbol, PMA significantly increases the likelihood that a single fast- or slow-phase presynaptic stimulus will elicit a postsynaptic action potential (fast-phase $\mathrm{RR}=6.933,{ }^{*} p=0.0002$; slow-phase $\mathrm{RR}=2.889,{ }^{*} p=0.0004$; both Fisher's exact test). $N$ values indicate number of pairs recorded following 4- $\alpha$-phorbol or PMA treatment.

physiological assays (DeRiemer et al., 1985a,b; Zhang et al., 2002). Pairs of cultured bag cell neurons were incubated for 20 min in $100 \mathrm{nM}$ of either 4- $\alpha$-phorbol or PMA, followed by wholecell voltage clamp at $-60 \mathrm{mV}$. Rather than assay the junction with a single test voltage, neuron 1 was stepped in $200 \mathrm{~ms}, 10 \mathrm{mV}$ intervals from -90 to $0 \mathrm{mV}$ (Fig. 4C, top) while maintaining neuron 2 at $-60 \mathrm{mV}$ (Fig. 4C, middle). This elicited a series of linear junctional currents that were relatively modest in $4-\alpha$-phorbol $(n=$ 10) (Fig. $4 C$, bottom), but considerably greater in PMA $(n=28)$
(Fig. 4D). When the junctional currents were averaged and plotted against the presynaptic test potential, a comparison found the difference between the two conditions to be significant at each voltage (Fig. 4F). Accordingly, the slope of the current-voltage relationship was at least twice as steep in PMA compared with 4 - $\alpha$-phorbol, consistent with a PKC-induced increase in junctional conductance.

Because PKC activation can impact membrane conductances (see Bag cell neuron voltage-gated $\mathrm{Ca}^{2+}$ current is enhanced by 


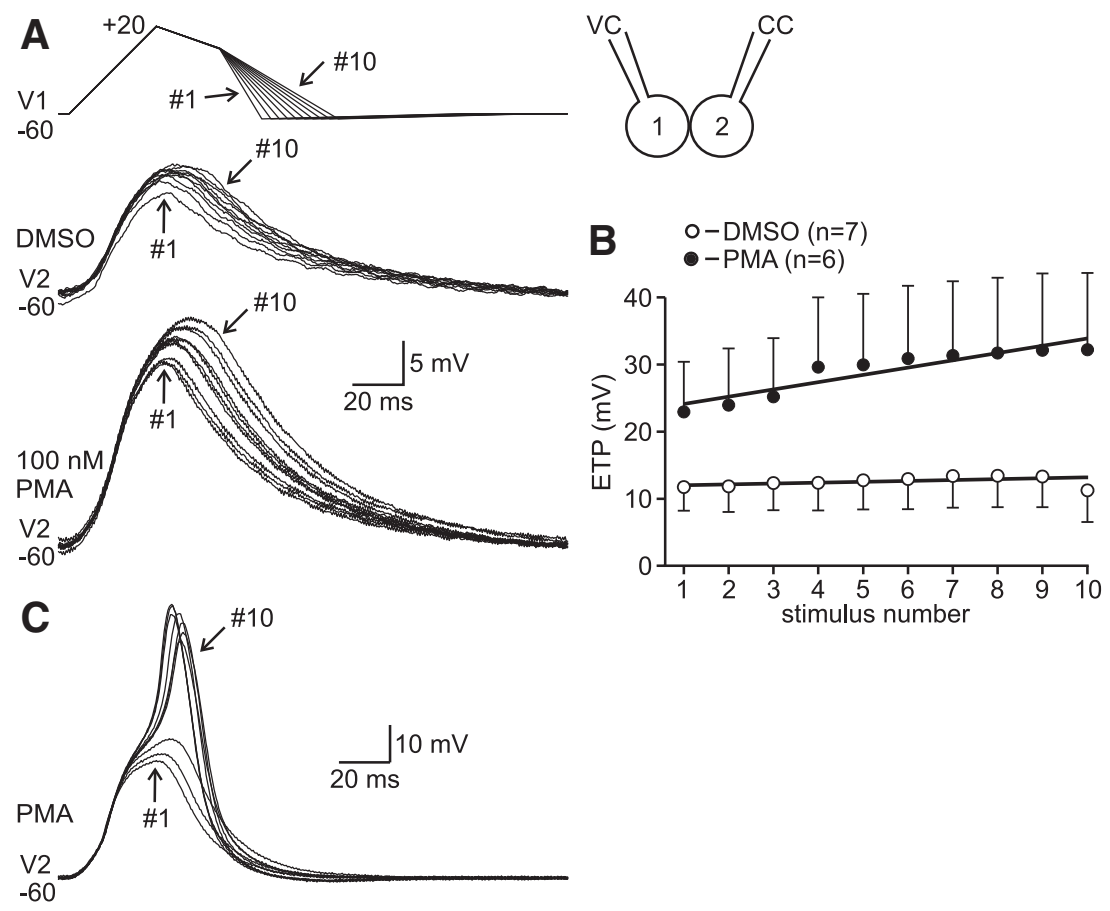

Figure 6. Broadening of the input stimulus evokes larger electrotonic potentials when PKC is activated. $\boldsymbol{A}$, Neuron 1 from an electrically coupled bag cell neuron pair is voltage-clamped at $-60 \mathrm{mV}$, whereas the membrane potential of neuron 2 is initially set to $-60 \mathrm{mV}$ in current clamp (inset). Ten action potential waveforms resembling the input stimulus are applied to neuron 1 at a frequency of $5 \mathrm{~Hz}$ (V1; top). As the half-width of each successive stimulus is broadened by $\sim 1 \mathrm{~ms}$ (compare waveform 1 to 10), it evokes an ETP in neuron 2 (V2). A pair treated for 30 min with DMSO before recording presents an ETP that gradually increases in size during the 10 waveform stimulus train (middle). This is far more evident when a different pair is previously incubated with $100 \mathrm{~nm}$ PMA, yielding an ETP that clearly grows over time (bottom). Numbers indicate the ETP following waveforms 1-10. Scale bars apply to the middle and bottom panels; abscissa also applies to the top panel. $\boldsymbol{B}$, Summary data for DMSO-treated (clear circles) and PMA-treated (black circles) pairs. The ETPs in PMA show a significant upward trend $\left(F_{(1,54)}=16.8537 p<0.04\right.$, repeated-measures ANOVA; $p=0.0001$, test for linear trend) compared with those in DMSO $\left(F_{(1,54)}=6.2154, p>0.05\right.$, repeated-measures ANOVA). Top and bottom error bars for PMA and DMSO datasets, respectively, removed for clarity. $N$ values indicate number of pairs recorded following DMSO or PMA treatment. C, Example of one of two additional pairs exposed to PMA, where the stimulus train eventually leads to action potentials in neuron 2 (V2).

PKC activation) (DeRiemer et al., 1985b; Strong et al., 1987; Zhang et al., 2002, 2008), changes to the presynaptic membrane could influence junctional current measurements. In an effort to account for this, we also measured the end-pulse membrane current in neuron 1 during the $200 \mathrm{~ms}$ steps while holding neuron 2 at $-60 \mathrm{mV}$. Specifically, the analysis examined the presynaptic membrane current between -90 and $-40 \mathrm{mV}$, which represents the voltage-independent portion of the membrane conductance. Beyond $-40 \mathrm{mV}$, the membrane conductance is strongly governed by voltage-dependent channels (again, see below). Comparing 4 - $\alpha$-phorbol $(n=10)$ to PMA $(n=28)$ found no significant difference in the membrane current of neuron $1(-90 \mathrm{mV}$ : $-205 \pm 52 \mathrm{pA}$ in $4-\alpha$-phorbol vs $-280 \pm 52 \mathrm{pA}$ in PMA, $t_{(11)}=$ $1.369, p>0.05 ;-80 \mathrm{mV}:-120 \pm 38 \mathrm{pA}$ in $4-\alpha$-phorbol vs $-140 \pm 11 \mathrm{pA}$ in PMA, $t_{(10)}=0.504, p>0.05 ;-70 \mathrm{mV}:-60 \pm$ $20 \mathrm{pA}$ in $4-\alpha$-phorbol vs $-62 \pm 5 \mathrm{pA}$ in PMA, $t_{(10)}=0.833, p>$ 0.05 ; $-50 \mathrm{mV}: 80 \pm 21 \mathrm{pA}$ in $4-\alpha$-phorbol vs $77 \pm 5 \mathrm{pA}$ in PMA, $t_{(10)}=0.142, p>0.05 ;-40 \mathrm{mV}: 191 \pm 45 \mathrm{pA}$ in $4-\alpha$-phorbol vs $153 \pm 11 \mathrm{pA}$ in PMA, $\left.t_{(10)}=0.822, p>0.05\right)$.

\section{PKC activation augments electrical transmission}

To see whether the PKC-induced change in junctional current impacted the electrical transmission of voltage signals, pairs were examined using presynaptic voltage clamp and postsynaptic current clamp (Fig. 5A, left inset). Because PKC is not turned on until the afterdischarge has started (Wayne et al., 1999), only the fastand slow-phase action potential-like waveforms were applied to neuron 1 voltage-clamped at $-40 \mathrm{mV}$ (Fig. $5 \mathrm{~A}$, middle and right insets) while recording the membrane potential response in neuron 2 , initially set to $-40 \mathrm{mV}$ with bias current. In DMSO $(n=10)$, neuron 2 most often displayed only an ETP when neuron 1 received either waveform and fired an action potential only approximately one-third of the time (Fig. $5 A, B$, left). However, if PKC was activated with 100 nM PMA beforehand $(n=11)$, then approximately three-fourths of the time neuron 2 exhibited spikes that clearly overshot $0 \mathrm{mV}$ when neuron 1 was given the stimuli (Fig. $5 A, B$, right). This difference in the instances of action potential occurrence was significant (Fig. 5C).

We also tested whether repetitive presynaptic stimulation was effectively relayed to the postsynaptic cell by supplying neuron 1 with two fast- or slow-phase spike-like waveforms at the physiological rate of 5 or $1 \mathrm{~Hz}$, respectively (for details, see Introduction). For DMSO $(n=10)$, neuron 2 fired dual action potentials with successive fast- or slow-phase stimuli in $20 \%$ and $40 \%$ of cases, respectively. On the other hand, exposure to $100 \mathrm{~nm}$ PMA $(n=11)$ led to neuron 2 spiking twice in $55 \%$ and $90 \%$ of instances. Figure $5 D$ provides a PMA-treated example of a double postsynaptic action potential response to two presynaptic slow-phase spike-like waveforms. This difference in the occurrence of dual action potential firing was significant for the slow- but not the fast-phase stimuli (Fig. 5E).

Finally, to again control for any off-target effects of PMA, neuronal pairs were treated for $20 \mathrm{~min}$ with $100 \mathrm{nM}$ of either 4- $\alpha$-phorbol or PMA, and the single fast- or slow-phase action potential-like waveforms were delivered to neuron 1. With 4- $\alpha$ phorbol $(n=10)$, neuron 2 always failed to reach threshold to the fast-phase stimulus or fired a spike only a fifth of the time to the slow-phase stimulus (Fig. 5F, left, $G$ ). As expected, with PMA $(n=26)$, both the fast- and slow phase stimulus evoked a postsynaptic action potential in $65 \%$ and $90 \%$ of pairs tested (Fig. $5 F$, right, $G$ ). The difference in the ability of the two stimuli to produce spikes in neuron 2 was significant between 4 - $\alpha$-phorbol and PMA (Fig. 5G).

A hallmark of the bag cell neuron action potential is that, when evoked from a resting potential of $-60 \mathrm{mV}$, it presents clear use-dependent broadening (Kaczmarek and Strumwasser, 1981; Kaczmarek et al., 1982; Whim and Kaczmarek, 1998). The broadening effect was mimicked by giving neuron 1 the input-phase action potential-like waveform 10 times, with the half-width of each stimulus after the first waveform increasing by $1 \mathrm{~ms}$ (Fig. $6 \mathrm{~A}$, top). Following a 20-30 min treatment with either DMSO or 100 
nM PMA, this stimulus train was presented to pairs where neuron 1 was held at $-60 \mathrm{mV}$ in voltage clamp and neuron 2 originally set at $-60 \mathrm{mV}$ under current clamp (Fig. $6 A$, inset). In DMSO $(n=7)$, the broadening waveforms in neuron 1 evoked ETPs from neuron 2 that modestly grew in amplitude over time (Fig. 6A, middle). By comparison, when PKC was activated $(n=6)$, the ETPs became noticeably larger as the stimulus train proceeded (Fig. 6A, bottom). The progressive increase in ETP magnitude with PMA was found to be a significant linear trend; conversely, the postsynaptic response to the stimulus train in DMSO did not trend significantly away from a slope of zero (Fig. 6B). Moreover, in two additional pairs, when PKC was activated, neuron 2 fired action potentials approximately halfway through the stimulus train, with each subsequent ETP reaching threshold (Fig. 6C).

\section{Activating PKC enhances the} responsiveness of bag cell neurons to a junctional current-like stimulus

The enhancement of electrical transmission by PKC may reflect a greater junctional current (Fig. 4) or a change in postsynaptic responsiveness. To investigate the latter, a more physiological, junctional current-like stimulus was used to test bag cell neuron excitability following PKC activation. This stimulus was derived by quantifying the junctional current between coupled bag cell neurons elicited by the presynaptic fast-phase action potential-like waveform. We choose to focus on the fast-phase because, following PMA treatment, waveforms based on both the fast- and slow-phase spike were essentially equal in their ability to provoke postsynaptic firing (Fig. 5C). Under dual voltage clamp, both cells were held at $-40 \mathrm{mV}$, and neuron 1 received the waveform stimulus (Fig. $7 \mathrm{~A}$, top), eliciting a junctional current in neuron $2(n=11)$ (Fig. $7 A$, bottom). This represents the current that flows through the gap junction from neuron 1 to neuron 2 in the absence of PKC activation. The average peak amplitude of the junctional current was shown to be $\sim-300 \mathrm{pA}$, with an area of $\sim-10 \mathrm{nA} \times \mathrm{ms}$ (Fig. 7B).

At this point, an approximation of the fast-phase junctional current was applied to single bag cell neurons initially set to -40 $\mathrm{mV}$ under current clamp. Based on a depolarizing version of the aforementioned average (compare Fig. 7A, bottom with Fig. $7 C$, top), the current was ramped from 0 to $300 \mathrm{pA}$ in $20 \mathrm{~ms}$ and then back down to $0 \mathrm{pA}$ in $60 \mathrm{~ms}$. Neurons were treated with either DMSO or 100 nM PMA for 20-30 min before recording. Neurons in DMSO $(n=9)$ displayed action potential firing in response to the fast-phase junctional current injection $44 \%$ of the time (Fig. $7 C$, middle). In contrast, cells given PMA $(n=8)$ always fired action potential in response to the stimulus (Fig. $7 C$, bottom). Not only was the occurrence of action potentials significantly higher with PMA (Fig. 7D), but so too were spike amplitude and area (Fig. $7 E, F)$.

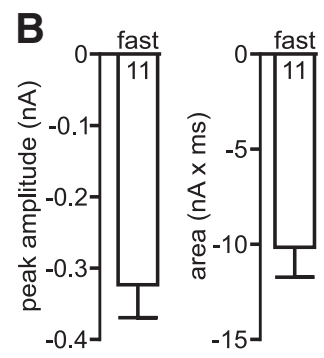

$C_{\text {lj fast-phase }}$
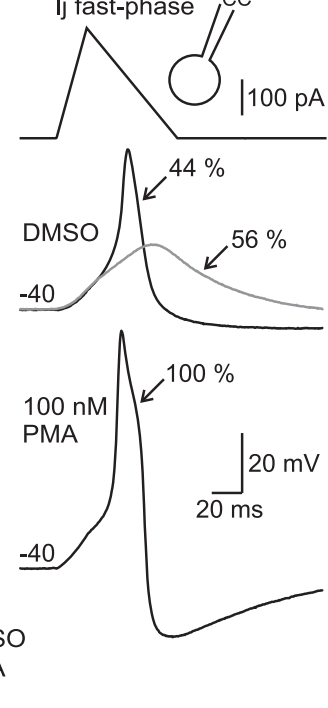

Figure 7. Following PKC activation, a fast-phase junctional current-like stimulus evokes action potentials more frequently. average action potential amplitude $(\boldsymbol{D})$ or area $(\boldsymbol{E})$ is significantly greater when PKC is activated by PMA (amplitude, $t_{(9)}=2.531$, ${ }^{*} p<0.04$; area, $t_{(9)}=3.333,{ }^{*} p<0.009$; both unpaired Student's $t$ test).

\section{Bag cell neuron voltage-gated $\mathrm{Ca}^{2+}$ current is enhanced by PKC activation}

It appeared that, in addition to altering junctional current, PMA heightened postsynaptic responsiveness. To look at the mechanism of this change in responsiveness, we first performed a simple assay of input resistance in individual bag cell neurons treated for 20-30 min with DMSO or $100 \mathrm{~nm}$ PMA before whole-cell current clamp measurements. Cells were first set to $-40 \mathrm{mV}$ with bias current and then injected with a $-50 \mathrm{pA}, 1 \mathrm{~s}$ square pulse of negative current. The resulting steady-state hyperpolarization was then used to determine input resistance. There was no significant difference between the input resistance of neurons in $\operatorname{DMSO}(n=9 ; 172 \pm 41 \mathrm{M} \Omega)$ versus PMA $(n=8 ; 220 \pm 59 \mathrm{M} \Omega)$ $\left(t_{(15)}=0.6839, p>0.05\right.$; unpaired Student's $t$ test $)$.

A lack of an effect on input resistance suggested that PMA may modify excitability by impacting active, rather than passive, membrane properties. In keeping with this, the afterdischarge is accompanied by a PKC-dependent increase in voltage-gated $\mathrm{Ca}^{2+}$ current, due to the membrane insertion of a second type of $\mathrm{Ca}^{2+}$ channel (DeRiemer et al., 1985b; Strong et al., 1987; Zhang et al., 2008). Thus, there is a distinct possibility that a change in postsynaptic $\mathrm{Ca}^{2+}$ current contributes to the enhanced postsynaptic responsiveness and electrical transmission following PKC activation in paired bag cell neurons. The ability of PKC to boost $\mathrm{Ca}^{2+}$ current was confirmed here by bathing single bag cell neurons in $\mathrm{Ca}^{2+}{ }_{-} \mathrm{Cs}^{+}$-TEA ASW and using a $\mathrm{Cs}^{+}$-Asp-based intracellular saline under whole-cell voltage clamp (Fig. $8 A$, inset) (for 
A

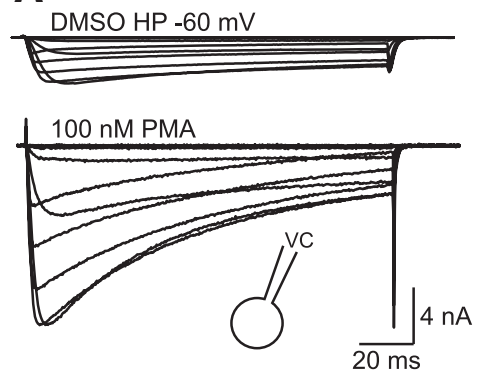

\section{C fast-phase ETP}

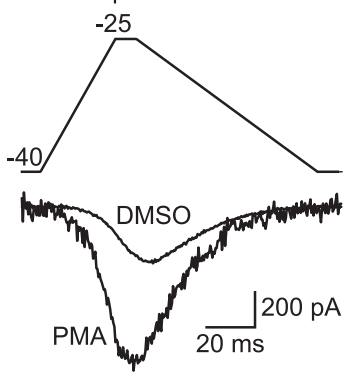

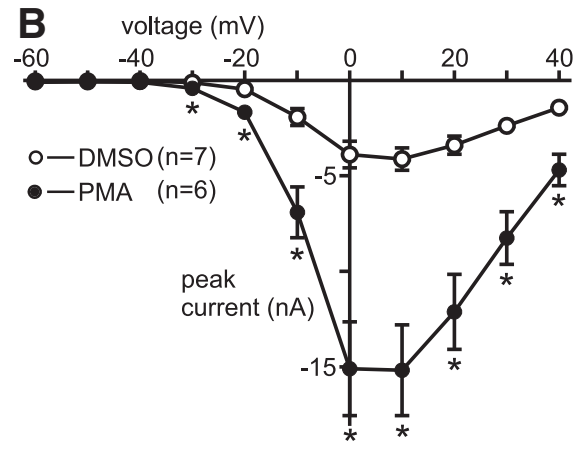

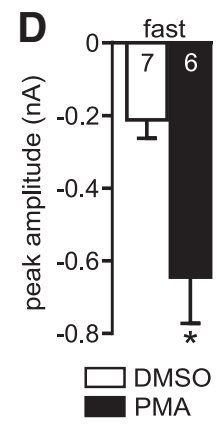

Figure 8. Activation of PKC enhances bag cell neuron $\mathrm{Ca}^{2+}$ current evoked by a waveform that mimics an electrotonic potential. $A$, Single bag cell neurons are bathed in $\mathrm{Ca}^{2+}-\mathrm{Cs}^{+}-$TEA ASW and treated with either DMSO or $100 \mathrm{~nm}$ PMA for 20 -30 min before whole-cell voltage clamp using a $\mathrm{Cs}^{+}$-Asp-based intracellular saline (inset). Stepping the neurons from a holding potential (HP) of $-60 \mathrm{mV}$ to $40 \mathrm{mV}$ in $200 \mathrm{~ms}, 10 \mathrm{mV}$ intervals, evokes a voltage-dependent $\mathrm{Ca}^{2+}$ current that is modestly inactivating during the test pulse. Compared with a neuron given DMSO (top), the current from a cell exposed to PMA (bottom) is three-fold larger. Scale bar applies to both traces. $\boldsymbol{B}$, Plotting peak $\mathrm{Ca}^{2+}$ current against step voltage reveals a nonlinear, voltage-dependent relationship. The current is inward and peaks between 0 and $10 \mathrm{mV}$ for both DMSO (clear circles) and PMA (black circles). Yet, the peak in PMA is significantly greater than DMSO at potentials more positive than $-30 \mathrm{mV}\left(-30 \mathrm{mV}, t_{(5)}=3.404,{ }^{*} p<0.02 ;-20 \mathrm{mV}\right.$, $t_{(5)}=3.106,{ }^{*} p<0.03 ;-10 \mathrm{mV}, t_{(6)}=3.568,{ }^{*} p<0.02 ; 0 \mathrm{mV}, t_{(5)}=4.369,{ }^{*} p<0.008 ; 10$ $\mathrm{mV}, t_{(5)}=3.872,{ }^{*} p<0.02 ; 20 \mathrm{mV}, t_{(5)}=4.282,{ }^{*} p<0.08 ; 30 \mathrm{mV}, t_{(5)}=4.115,{ }^{*} p<0.01$; $40 \mathrm{mV}, t_{(5)}=3.744,{ }^{*} p<0.02$; all unpaired Student's $t$ test). $N$ values indicate number of individual neurons recorded following DMSO or PMA. C, A fast-phase ETP-like waveform (top) is given to single bag cell neurons voltage-clamped at $-40 \mathrm{mV}$ while recording $\mathrm{Ca}^{2+}$ current. The waveform elicits an $\sim 200 \mathrm{pA}$ current in a neuron treated with DMSO beforehand (gray trace; bottom). By comparison, a cell in PMA displays a two-fold larger $\mathrm{Ca}^{2+}$ current (black trace; bottom). Abscissa also applies to the top panel. $\boldsymbol{D}$, The peak amplitude of the ETP-like waveform-induced $\mathrm{Ca}^{2+}$ current is significantly greater in PMA versus DMSO $\left(t_{(11)}=3.353\right.$, ${ }^{*} p<0.007$; unpaired Student's $t$ test). Nvalues indicate number of individual neurons recorded following DMSO or PMA.

details, see Whole-cell, voltage- and current-clamp recording from bag cell neurons). Cells were exposed to either DMSO or 100 nM PMA for 20-30 min before recording, where they were held at $-60 \mathrm{mV}$ and pulsed through a series of $10 \mathrm{mV}, 200 \mathrm{~ms}$ steps from -60 to $40 \mathrm{mV}$. This evoked a voltage-dependent, modestly inactivating, inward membrane $\mathrm{Ca}^{2+}$ current similar to what our laboratory and others have reported previously (Fig. 8A) (Conn et al., 1989; Fieber, 1995; Gardam et al., 2008; Tam et al., 2009; Groten and Magoski, 2015). The currents from PMAtreated neurons $(n=6)$ were typically several times larger than in cells given DMSO $(n=7)$ (Fig. $8 A$, top vs bottom). Plotting peak $\mathrm{Ca}^{2+}$ current against step voltage revealed an onset $\sim-30 \mathrm{mV}$ and a maximum between 0 and $10 \mathrm{mV}$. The group data for DMSO versus PMA showed that this voltage dependence was essentially the same; however, the maximal current was a near three-fold greater in PMA, with significant differences at test potentials from -30 to $40 \mathrm{mV}$ (Fig. 8B).
Within the context of electrical transmission, it was important to determine whether the ETP was capable of recruiting $\mathrm{Ca}^{2+}$ current, and what impact PKC may have on this outcome. This was evaluated by delivering a fast-phase ETP-like waveform under voltage clamp: a voltage waveform was constructed similar in shape and size to the postsynaptic ETP produced in response to the presynaptic fast-phase action potential-like stimulus in DMSO/control conditions. Specifically, the membrane potential was ramped from -40 to $-25 \mathrm{mV}$ in $35 \mathrm{~ms}$, followed by holding at $-25 \mathrm{mV}$ for $10 \mathrm{~ms}$, then ramping to $-40 \mathrm{mV}$ in $85 \mathrm{~ms}$ (Fig. $8 C$, top). The waveform was applied to single whole-cell voltageclamped neurons recorded with the same solutions described above for isolating $\mathrm{Ca}^{2+}$ current. After DMSO treatment, the ETP-like waveform was capable of eliciting a modest $\mathrm{Ca}^{2+}$ current of a couple of hundred pA $(n=7)$, whereas the response was clearly bigger in PMA $(n=6)$ (Fig. $8 C$, bottom). On average, this enhancement was again approximately three-fold and significantly different from control (Fig. 8D).

\section{Discussion}

Synchronized interactions mediated by electrical coupling are common for neuroendocrine cells from many species (for review, see Bosco et al., 2011; Magoski, 2017). In Aplysia, when cholinergic input from higher centers triggers a bag cell neuron afterdischarge, it is synchronous due to electrical synapses within the cluster, and leads to the aggregate release of egg-laying hormone (Kupfermann and Kandel, 1970; Blankenship and Haskins, 1979; Stuart et al., 1980; Michel and Wayne, 2002; White and Magoski, 2012; Dargaei et al., 2014). Coordination of the burst requires reliable neuron-to-neuron action potential propagation. Thus, our finding that PKC enhances electrical transmission and feedforward excitation between bag cell neurons is consistent with the en masse nature of the afterdischarge.

The coupling observed here is comparable with prior work by ourselves and others, where cultured bag cell neurons form electrical synapses after 1-3 d in vitro (Kaczmarek et al., 1979; Dargaei et al., 2014, 2015). Under dual voltage clamp, a presynaptic depolarizing or hyperpolarizing step evokes an almost immediate postsynaptic inward or outward current, respectively. Furthermore, under presynaptic voltage clamp and postsynaptic current clamp, the onset of the ETP is well before the peak of the action potential-like waveform. This is typical of electrical transmission, which has an ultrashort latency and usually lacks polarity (both positive and negative stimuli transfer equally); conversely, chemical transmission normally occurs only upon presynaptic depolarization and has an obvious latency, representing the time for transmitter release, diffusion, and binding (Hagiwara and Tasaki, 1958; Grundfest, 1961; Bennett et al., 1963; Katz and Miledi, 1967). Finally, the ETP is sensitive to the gap junction blockers, NPPB and NFA, which have been found to inhibit not only junctional current in bag cell neurons, but also mammalian connexins in expression systems, as well as electrical transmission between neurons from rabbit retina or the pulmonate snail, Lymnaea stagnalis (Harks et al., 2001; Eskandari et al., 2002; Srinivas and Spray, 2003; Pan et al., 2007; Dargaei et al., 2014; Beekharry et al., 2015).

The junctional conductance measured here lacks obvious voltage dependence between -90 and $0 \mathrm{mV}$, which agrees with our earlier efforts (Dargaei et al., 2014). However, the present study also tests potentials more positive than previously applied $(10-60 \mathrm{mV})$, over which the junctional current does show modest decrease. This is not all that surprising, given that gap junctions from both the salivary gland of the midge, Chironomus 
thummi, and giant fiber system of the fruit fly, Drosophila melanogaster, as well as various forms of heterologously expressed vertebrate connexins, are voltage-dependent (Obaid et al., 1983; Bukauskas and Verselis, 2004; Phelan et al., 2008). That aside, the voltage-dependent decrease of the bag cell neuron junctional current is weak and only apparent at potentials $>0 \mathrm{mV}$, meaning it would have little impact on synchrony, even with strong depolarization or at the peak of the action potential.

Electrical synapses serve as low-pass filters, on account of the junctional current having to charge the postsynaptic membrane capacitance (Bennett and Zukin, 2004). For bag cell neurons, this results in attenuation and slowing of postsynaptic responses relative to the presynaptic voltage change. Specifically, a 70 to $80 \mathrm{mV}$ presynaptic spike-like waveform is reduced to an $\sim 20 \mathrm{mV}$ postsynaptic ETP. Also, while the latency of the junctional current is certainly short, the time required to reach the peak of the ETP is still $>20 \mathrm{~ms}$. Consequently, the ETP evoked by either the fast- or slow-phase action potential-like waveform under control conditions elicits a postsynaptic spike $<30 \%$ of the time. In the cluster, this would have implications for action potential spread and/or maintenance of synchronous firing. However, this may be offset by PKC enhancing electrical transmission and increasing the probability of postsynaptic spiking. Because PKC is upregulated 1-2 min following afterdischarge onset, it may contribute to network bursting (Conn et al., 1989; Wayne et al., 1999).

When PKC is activated by treating bag cell neuron pairs with PMA, but not DMSO (the vehicle) or 4- $\alpha$-phorbol (an inactive PMA analog), the junctional conductance is increased. In particular, the slope of the junctional current-voltage relationship in PMA is approximately twice that of control, consistent with greater junctional conductance. This is unusual, given that most reports indicate PKC inhibits gap junctions (for review, see Lampe and Lau, 2000, 2004; Pogoda et al., 2016), including endogenous or heterologously expressed connexins in rat lacrimal glands, mouse pancreatic acinar cells, rat kidney cells, human FL cells, or HeLa cells (Enomoto et al., 1981; Randriamampita et al., 1988; Somogyi et al., 1989; Li et al., 1996). PKC-mediated phosphorylation of connexins, such as those from rat epithelial T51B cells, fibroblasts, v79 cells, or purified gap junction protein in proteoliposomes, correlates with inhibition (Lampe et al., 2000; Cruciani et al., 2001; Bao et al., 2004). Studies on connexin 43 show $\mathrm{PKC}$ reduces gap junction assembly and/or membrane halflife (Solan et al., 2003; Laird, 2005; Liao et al., 2013; Cone et al., 2014). For gap junctions from neurons or neuron-derived cell lines, such as mouse hippocampal HT22 cells, human neuroblastoma, or rodent hypothalamic and somatosensory cortical neurons, the effect of PKC is again inhibitory (Lin and Takemoto, 2007; Morley et al., 2010; Park et al., 2011). Aside from a report that PMA increases coupling between rat neonatal cardiomyocytes (Kwak et al., 1995), to the best of our knowledge, the present study is a novel instance where junctional current is enhanced by PKC activation in neurons. A possible mechanism could be greater conductance following phosphorylation of bag cell neuron gap junction channels or a longer channel lifetime at the membrane due to more recruitment and/or less retrieval.

Along with augmented junctional current, PKC activation also promotes feedforward excitation and improves the fidelity of transmission between electrically coupled bag cell neurons. Following PMA, presynaptic fast- and slow-phase action potentiallike waveforms routinely evoke postsynaptic spikes from an after discharge-like membrane potential of $-40 \mathrm{mV}$. While elevated junctional current likely contributes to feedforward excitation, our data also indicate a role for changes to postsynaptic responsiveness i.e., a PKC-dependent increase in voltage-dependent $\mathrm{Ca}^{2+}$ current. In single bag cell neurons, triggering PKC with PMA enhances the $\mathrm{Ca}^{2+}$ current by three-fold, as assayed with voltage steps or, importantly, an ETP-like waveform. Moreover, when individual neurons are given a junctional current-like stimulus, they are much more likely to fire an action potential if PKC has been activated. Prior studies in bag cell neurons offer strong evidence that PKC recruits a second type of $\mathrm{Ca}^{2+}$ channel, $\mathrm{Ca}_{\mathrm{v}} 2$, to the plasma membrane (DeRiemer et al., 1985b; Strong et al., 1987; Zhang et al., 2008). This insertion alters excitability, in so much that delivery of a suprathreshold stimulus (step current) causes taller action potentials (DeRiemer et al., 1985b; Groten and Magoski, 2015). When we provide a largely subthreshold stimulus (i.e., a synaptically induced ETP for pairs or a junctional current-like stimulus for single cells), the neurons spike far more often in PMA compared with DMSO or 4- $\alpha$-phorbol controls.

Electrical coupling recruits postsynaptic currents to promote firing synchrony in other networks, such as guinea pig cerebellar interneurons and goldfish Mauthner neuron to club ending synapses, as well as rat mesencephalic trigeminal sensory neurons or thalamic reticular neurons (Mann-Metzer and Yarom, 1999; Curti and Pereda, 2004; Curti et al., 2012; Haas and Landisman, 2012). These examples all involve a presynaptic spike generating an ETP, which in turn activates subthreshold postsynaptic voltagegated $\mathrm{Na}^{+}$current, that eventually evokes an action potential. Bag cell neurons use $\mathrm{Ca}^{2+}$ current rather than $\mathrm{Na}^{+}$current for similar purposes. Moreover, bag cell neuron $\mathrm{Ca}^{2+}$ current displays a persistent component, particularly between -40 and $-20 \mathrm{mV}$ (Tam et al., 2009). This voltage range is within what would be produced by an ETP; thus, if PKC boosts junctional and postsynaptic $\mathrm{Ca}^{2+}$ current, an ETP would be more likely to cause postsynaptic firing.

Electrical synapses may support the all-or-none aspect of the bag cell neuron afterdischarge: once a high threshold is exceeded, the burst quickly spreads throughout the cluster (Kupfermann and Kandel, 1970; Brown and Mayeri, 1989). This is reflected in our prior report that gap junction blockers, NPPB and NFA, not only disrupt electrical coupling in the intact cluster, but also prevent the afterdischarge all together (Dargaei et al., 2014). The input that triggers the afterdischarge is thought to innervate at least a subset of bag cell neurons (Brown and Mayeri, 1989); therefore, the effect of PKC on junctional and voltage-gated $\mathrm{Ca}^{2+}$ current could aid in overcoming any low-pass filtering of action potentials and encourage electrotonic spread through the network. The production of burst firing from maintained depolarization of individual neurons in a network is also prevalent in both the escape swim circuit of the nudibranch marine snail, Tritonia diomedia, and the jaw-muscle spindle afferents of the rat trigeminal nucleus (Getting and Willows, 1974; Curti et al., 2012). For those neurons, depolarization of the population generates ETPs that eventually lead to synchronous firing. In Aplysia, we propose that enhanced feedforward excitation via electrical transmission results in regenerative firing, population synchrony, and ultimately the secretion of reproductive hormone.

\section{References}

Arch S, Smock T (1977) Egg-laying behavior in Aplysia californica. Behav Biol 19:45-54. CrossRef

Azhderian EM, Kaczmarek LK (1991) Phosphorylation of membraneassociated proteins by phorbol esters in isolated bag cell neurons of Aplysia. J Neurobiol 22:105-115. CrossRef Medline

Bao X, Reuss L, Altenberg GA (2004) Regulation of purified and reconstituted connexin 43 hemichannels by protein kinase C-mediated phosphorylation of serine 368. J Biol Chem 279:20058-20066. CrossRef Medline

Beekharry CC, Zhu GZ, Magoski NS (2015) Role for electrical synapses in 
shaping the output of coupled peptidergic neurons from Lymnaea. Brain Res 1603:8-21. CrossRef Medline

Belin V, Moos F (1986) Paired recordings from supraoptic and paraventricular oxytocin cells in suckled rats: recruitment and synchronization. J Physiol 377:369-390. CrossRef Medline

Bennett MV (1966) Physiology of electrotonic junctions. Ann N Y Acad Sci 137:509-539. CrossRef Medline

Bennett MV (2000) Seeing is believing: electrical synapses between visualized neurons. Nat Neurosci 3:7-9. CrossRef Medline

Bennett MV, Zukin RS (2004) Electrical coupling and neuronal synchronization in the mammalian brain. Neuron 41:495-511. CrossRef Medline

Bennett MV, Aljure E, Nakajima Y, Pappas GD (1963) Electrotonic junctions between teleost spinal neurons: electrophysiology and ultrastructure. Science 141:262-264. CrossRef Medline

Blankenship JE, Haskins JT (1979) Electrotonic coupling among neuroendocrine cells in Aplysia. J Neurophysiol 42:347-355. CrossRef Medline

Bosco D, Haefliger JA, Meda P (2011) Connexins: key mediators of endocrine function. Physiol Rev 91:1393-1445. CrossRef Medline

Brown RO, Mayeri E (1989) Positive feedback by autoexcitory neuropeptides in neuroendocrine bag cells of Aplysia. J Neurosci 9:1443-1451. Medline

Bukauskas FF, Verselis VK (2004) Gap junction channel gating. Biochim Biophys Acta 1662:42-60. CrossRef Medline

Carew TJ, Kandel ER (1977) Inking in Aplysia californica: III. Two different synaptic conductance mechanisms for triggering central program for inking. J Neurophysiol 40:721-734. CrossRef Medline

Castagna M, Takai Y, Kaibuchi K, Sano K, Kikkawa U, Nishizuka Y (1982) Direct activation of calcium-activated, phospholipid-dependent protein kinase by tumor-promoting phorbol esters. J Biol Chem 257:7847-7851. Medline

Cone AC, Cavin G, Ambrosi C, Hakozaki H, Wu-Zhang AX, Kunkel MT, Newton AC, Sosinsky GE (2014) Protein kinase c-mediated phosphorylation of connexin 43 gap junction channels causes movement within gap junctions followed by vesicle internalization and protein degradation. J Biol Chem 289:8781-8798. CrossRef Medline

Conn PJ, Kaczmarek LK (1989) The bag cell neurons of Aplysia. Mol Neurobiol 3:237-273. CrossRef Medline

Conn PJ, Strong JA, Kaczmarek LK (1989) Inhibitors of protein kinase C prevent enhancement of calcium current and action potentials in peptidergic neurons of Aplysia. J Neurosci 9:480-487. Medline

Cruciani V, Husøy T, Mikalsen SO (2001) Pharmacological evidence for system-dependent involvement of protein kinase $\mathrm{C}$ isoenzymes in phorbol ester-suppressed gap junctional communication. Exp Cell Res 268: 150-161. CrossRef Medline

Curti S, Pereda AE (2004) Voltage-dependent enhancement of electrical coupling by a subthreshold sodium current. J Neurosci 24:3999-4010. CrossRef Medline

Curti S, Hoge G, Nagy JI, Pereda AE (2012) Synergy between electrical coupling and membrane properties promotes strong synchronization of neurons of the mesencephalic trigeminal nucleus. J Neurosci 32:43414359. CrossRef Medline

Dargaei Z, Colmers PL, Hodgson HM, Magoski NS (2014) Electrical coupling between Aplysia bag cell neurons: characterization and role in synchronous firing. J Neurophysiol 112:2680-2696. CrossRef Medline

Dargaei Z, Standage D, Groten CJ, Blohm G, Magoski NS (2015) $\mathrm{Ca}^{2+}$ induced uncoupling of Aplysia bag cell neurons. J Neurophysiol 113:808821. CrossRef Medline

DeRiemer SA, Greengard P, Kaczmarek LK (1985a) Calcium/phosphatidylserine/diacylglycerol-dependent protein phosphorylation in the Aplysia nervous system. J Neurosci 5:2672-2676. Medline

DeRiemer SA, Strong JA, Albert KA, Greengard P, Kaczmarek LK (1985b) Enhancement of calcium current in Aplysia neurones by phorbol ester and protein kinase C. Nature 313:313-316. CrossRef Medline

Enomoto T, Sasaki Y, Shiba Y, Kanno Y, Yamasaki H (1981) Tumor promoters cause a rapid and reversible inhibition of the formation and maintenance of electrical cell coupling in culture. Proc Natl Acad Sci U S A 78:5628-5632. CrossRef Medline

Ermentrout B, Wang JW, Flores J, Gelperin A (2004) Model for transition from waves to synchrony in the olfactory lobe of Limax. J Comput Neurosci 17:365-383. CrossRef Medline

Eskandari S, Zampighi GA, Leung DW, Wright EM, Loo DD (2002) Inhibition of gap junction hemichannels by chloride channel blockers. J Membr Biol 185:93-102. CrossRef Medline
Fieber LA (1995) Characterization and modulation of $\mathrm{Na}^{+}$and $\mathrm{Ca}^{2+}$ currents underlying the action potential in bag cells of two species of Aplysia. J Exp Biol 198:2337-2347. Medline

Fisher TE, Levy S, Kaczmarek LK (1994) Transient changes in intracellular calcium associated with a prolonged increase in excitability in neurons of Aplysia californica. J Neurophysiol 71:1254-1257. CrossRef Medline

Galarreta M, Hestrin S (1999) A network of fast-spiking cells in the neocortex connected by electrical synapses. Nature 402:72-75. CrossRef Medline

Gardam KE, Geiger JE, Hickey CM, Hung AY, Magoski NS (2008) Flufenamic acid affects multiple currents and causes intracellular $\mathrm{Ca}^{2+}$ release in Aplysia bag cell neurons. J Neurophysiol 100:38-49. CrossRef Medline

Geiger JE, Magoski NS (2008) $\mathrm{Ca}^{2+}$ induced $\mathrm{Ca}^{2+}$ release in Aplysia bag cell neurons requires interaction between mitochondrial and endoplasmic reticulum stores. J Neurophysiol 100:24-37. CrossRef Medline

Getting PA, Willows AO (1974) Modification of neuron properties by electrotonic synapses: II. Burst formation by electrotonic synapses. J Neurophysiol 37:858-868. CrossRef Medline

Gibson JR, Beierlein M, Connors BW (1999) Two networks of electrically coupled inhibitory neurons in neocortex. Nature 402:75-79. CrossRef Medline

Groten CJ, Magoski NS (2015) PKC enhances the capacity for secretion by rapidly recruiting covert voltage-gated $\mathrm{Ca}^{2+}$ channels to the membrane. J Neurosci 35:2747-2765. CrossRef Medline

Grundfest H (1961) Ionic mechanisms in electrogenesis. Ann N Y Acad Sci 94:405-457. CrossRef Medline

Haas JS, Landisman CE (2012) State-dependent modulation of gap junction signaling by the persistent sodium current. Front Cell Neurosci 5:31. CrossRef Medline

Hagiwara S, Tasaki I (1958) A study on the mechanism of impulse transmission across the giant synapse of the squid. J Physiol 143:114-137. CrossRef Medline

Hamill OP, Marty A, Neher E, Sakmann B, Sigworth FJ (1981) Improved patch-clamp techniques for high-resolution current recording from cells and cell-free membrane patches. Pflugers Arch 391:85-100. CrossRef Medline

Harks EG, de Roos AD, Peters PH, de Haan LH, Brouwer A, Ypey DL, van Zoelen EJ, Theuvenet AP (2001) Fenamates: a novel class of reversible gap junction blockers. J Pharmacol Exp Ther 298:1033-1041. Medline

Haskins JT, Blankenship JE (1979) Interactions between bilateral clusters of neuroendocrine cells in Aplysia. J Neurophysiol 42:356-367. CrossRef Medline

Hickey CM, Geiger JE, Groten CJ, Magoski NS (2010) Mitochondrial Ca ${ }^{2+}$ activates a cation current in Aplysia bag cell neurons. J Neurophysiol 103:1543-1556. CrossRef Medline

Hickey CM, Groten CJ, Sham L, Carter CJ, Magoski NS (2013) Voltagegated $\mathrm{Ca}^{2+}$ influx and mitochondrial $\mathrm{Ca}^{2+}$ initiate secretion from Aplysia neuroendocrine cells. Neuroscience 250:755-772. CrossRef Medline

Hung AY, Magoski NS (2007) Activity-dependent initiation of a prolonged depolarization in Aplysia bag cell neurons: role for a cation channel. J Neurophysiol 97:2465-2479. CrossRef Medline

Kaczmarek LK, Strumwasser F (1981) The expression of long lasting afterdischarge by isolated Aplysia bag cell neurons. J Neurosci 1:626-634. Medline

Kaczmarek LK, Strumwasser F (1984) A voltage-clamp analysis of currents underlying cyclic AMP-induced membrane modulation in isolated peptidergic neurons of Aplysia. J Neurophysiol 52:340-349. CrossRef Medline

Kaczmarek LK, Jennings KR, Strumwasser F (1982) An early sodium and a late calcium phase in the afterdischarge of peptide-secreting neurons of Aplysia. Brain Res 238:105-115. CrossRef Medline

Kaczmarek LK, Finbow M, Revel JP, Strumwasser F (1979) The morphology and coupling of Aplysia bag cells within the abdominal ganglion and in cell culture. J Neurobiol 10:535-550. CrossRef Medline

Katz B, Miledi R (1967) The timing of calcium action during neuromuscular transmission. J Physiol 189:535-544. CrossRef Medline

Kupfermann I, Kandel ER (1970) Electrophysiological properties and functional interconnections of two symmetrical neurosecretory clusters (bag cells) in abdominal ganglion of Aplysia. J Neurophysiol 33:865-876. CrossRef Medline

Kwak BR, van Veen TA, Analbers LJ, Jongsma HJ (1995) TPA increases conductance but decreases permeability in neonatal rat cardiomyocyte gap junction channels. Exp Cell Res 220:456-463. CrossRef Medline

Laird DW (2005) Connexin phosphorylation as a regulatory event linked 
to gap junction internalization and degradation. Biochim Biophys Acta 1711:172-182. CrossRef Medline

Lampe PD, Lau AF (2000) Regulation of gap junctions by phosphorylation of connexins. Arch Biochem Biophys 384:205-215. CrossRef Medline

Lampe PD, Lau AF (2004) The effects of connexin phosphorylation on gap junctional communication. Int J Biochem Cell Biol 36:1171-1186. CrossRef Medline

Lampe PD, TenBroek EM, Burt JM, Kurata WE, Johnson RG, Lau AF (2000) Phosphorylation of connexin 43 on serine 368 by protein kinase $\mathrm{C}$ regulates gap junctional communication. J Cell Biol 149:1503-1512. CrossRef Medline

Li H, Liu TF, Lazrak A, Peracchia C, Goldberg GS, Lampe PD, Johnson RG (1996) Properties and regulation of gap junctional hemichannels in the plasma membranes of cultured cells. J Cell Biol 134:1019-1030. CrossRef Medline

Liao CK, Cheng HH, Wang SD, Yeih DF, Wang SM (2013) PKC $\varepsilon$ mediates serine phosphorylation of connexin 43 induced by lysophosphatidylcholine in neonatal rat cardiomyocytes. Toxicology 314:11-21. CrossRef Medline

Lin D, Takemoto DJ (2007) Protection from ataxia-linked apoptosis by gap junction inhibitors. Biochem Biophys Res Commun 362:982-987. CrossRef Medline

Loechner KJ, Knox RJ, Connor JA, Kaczmarek LK (1992) Hyperosmotic media inhibit voltage-dependent calcium influx and peptide release in Aplysia neurons. J Membr Biol 128:41-52. Medline

Long MA, Jutras MJ, Connors BW, Burwell RD (2005) Electrical synapses coordinate activity in the suprachiasmatic nucleus. Nat Neurosci 8:6166. CrossRef Medline

Ma Y, Juntti SA, Hu CK, Huguenard JR, Fernald RD (2015) Electrical synapses connect a network of gonadotropin releasing hormone neurons in a cichlid fish. Proc Natl Acad Sci U S A 112:3805-3810. CrossRef Medline

Magoski NS (2017) Electrical synapses and neuroendocrine cell function. In: Network functions and plasticity: perspectives from studying neuronal electrical coupling in microcircuits (Jing J ed), pp 137-160. Amsterdam: Elsevier.

Magoski NS, Knox RJ, Kaczmarek LK (2000) Activation of a $\mathrm{Ca}^{2+}$ permeable cation channel produces a prolonged attenuation of intracellular $\mathrm{Ca}^{2+}$ release in Aplysia bag cell neurones. J Physiol 522:271-283. CrossRef Medline

Mann-Metzer P, Yarom Y (1999) Electrotonic coupling interacts with intrinsic properties to generate synchronized activity in cerebellar networks of inhibitory interneurons. J Neurosci 19:3298-3306. Medline

McCracken CB, Roberts DC (2006) Neuronal gap junctions: expression, function, and implications for behavior. Int Rev Neurobiol 73:125-151. CrossRef Medline

Michel S, Wayne NL (2002) Neurohormone secretion persists after postafterdischarge membrane depolarization and cytosolic calcium elevation in peptidergic neurons in intact nervous tissue. J Neurosci 22:9063-9069. Medline

Morley M, Jones C, Sidhu M, Gupta V, Bernier SM, Rushlow WJ, Belliveau DJ (2010) PKC inhibition increases gap junction intercellular communication and cell adhesion in human neuroblastoma. Cell Tissue Res 340:229242. CrossRef Medline

Obaid AL, Socolar SJ, Rose B (1983) Cell-to-cell channels with two independently regulated gates in series: analysis of junctional conductance modulation by membrane potential, calcium, and $\mathrm{pH}$. J Membr Biol 73:69-89. CrossRef Medline

Pan F, Mills SL, Massey SC (2007) Screening of gap junction antagonists on dye coupling in the rabbit retina. Vis Neurosci 24:609-618. CrossRef Medline

Park WM, Wang Y, Park S, Denisova JV, Fontes JD, Belousov AB (2011) Interplay of chemical neurotransmitters regulates developmental increase in electrical synapses. J Neurosci 31:5909-5920. CrossRef Medline

Phelan P, Goulding LA, Tam JL, Allen MJ, Dawber RJ, Davies JA, Bacon JP
(2008) Molecular mechanism of rectification at identified electrical synapses in the Drosophila giant fiber system. Curr Biol 18:1955-1960. CrossRef Medline

Pogoda K, Kameritsch P, Retamal MA, Vega JL (2016) Regulation of gap junction channels and hemichannels by phosphorylation and redox changes: a revision. BMC Cell Biol 17:137-150. CrossRef Medline

Randriamampita C, Giaume C, Neyton J, Trautmann A (1988) Acetylcholineinduced closure of gap junction channels in rat lacrimal glands is probably mediated by protein kinase C. Pflugers Arch 412:462-468. CrossRef Medline

Sáez JC, Nairn AC, Czernik AJ, Spray DC, Hertzberg EL, Greengard P, Bennett MV (1990) Phosphorylation of connexin 32, a hepatocyte gapjunction protein, by cAMP-dependent protein kinase, protein kinase $\mathrm{C}$ and $\mathrm{Ca}^{2+} /$ calmodulin-dependent protein kinase II. Eur J Biochem 192: 263-273. CrossRef Medline

Söhl G, Maxeiner S, Willecke K (2005) Expression and functions of neuronal gap junctions. Nat Rev Neurosci 6:191-200. CrossRef Medline

Solan JL, Fry MD, TenBroek EM, Lampe PD (2003) Connexin 43 phosphorylation at $\mathrm{S} 368$ is acute during $\mathrm{S}$ and $\mathrm{G}(2) / \mathrm{M}$ and in response to protein kinase C activation. J Cell Sci 116:2203-2211. CrossRef Medline

Somogyi R, Batzer A, Kolb HA (1989) Inhibition of electrical coupling in pairs of murine pancreatic acinar cells by OAG and isolated protein kinase C. J Membr Biol 108:273-282. CrossRef Medline

Sossin WS, Diaz-Arrastia R, Schwartz JH (1993) Characterization of two isoforms of protein kinase $\mathrm{C}$ in the nervous system of Aplysia californica. J Biol Chem 268:5763-5768. Medline

Spray DC, Burt JM (1990) Structure-activity relations of the cardiac gap junction channel. Am J Physiol 258:C195-C205. CrossRef Medline

Srinivas M, Spray DC (2003) Closure of gap junction channels by arylaminobenzoates. Mol Pharmacol 63:1389-1397. CrossRef Medline

Strong JA, Fox AP, Tsien RW, Kaczmarek LK (1987) Stimulation of protein kinase $\mathrm{C}$ recruits covert calcium channels in Aplysia bag cell neurons. Nature 325:714-717. CrossRef Medline

Stuart DK, Chiu AY, Strumwasser F (1980) Neurosecretion of egg-laying hormone and other peptides from electrically active bag cell neurons of Aplysia. J Neurophysiol 43:488-498. CrossRef Medline

Sturgeon RM, Magoski NS (2016) Diacylglycerol-mediated regulation of Aplysia bag cell neuron excitability requires protein kinase C. J Physio 594:5573-5592. CrossRef Medline

Tam AK, Geiger JE, Hung AY, Groten CJ, Magoski NS (2009) Persistent $\mathrm{Ca}^{2+}$ current contributes to a prolonged depolarization in Aplysia bag cell neurons. J Neurophysiol 102:3753-3765. CrossRef Medline

Tam A, Gardam K, Lamb S, Kachoei B, Magoski NS (2011) Role for protein kinase $\mathrm{C}$ in controlling Aplysia bag cell neuron excitability. Neuroscience 179:41-55. CrossRef Medline

Wayne NL, Lee W, Kim YJ (1999) Persistent activation of calcium-activated and calcium-independent protein kinase $\mathrm{C}$ in response to electrical afterdischarge from peptidergic neurons of Aplysia. Brain Res 834:211-213. CrossRef Medline

Whim MD, Kaczmarek LK (1998) Heterologous expression of the Kv3.1 potassium channel eliminates spike broadening and the induction of a depolarizing afterpotential in the peptidergic bag cell neurons. J Neurosci 18:9171-9180. Medline

White SH, Magoski NS (2012) Acetylcholine-evoked afterdischarge in Aplysia bag cell neurons. J Neurophysiol 107:2672-2685. CrossRef Medline

Zhang Y, Kaczmarek LK (2008) Bag cell neurons. Scholarpedia 3:4095. CrossRef

Zhang Y, Magoski NS, Kaczmarek LK (2002) Prolonged activation of $\mathrm{Ca}^{2+}$-activated $\mathrm{K}^{+}$current contributes to the long-lasting refractory period of Aplysia bag cell neurons. J Neurosci 22:10134-10141. Medline

Zhang Y, Helm JS, Senatore A, Spafford JD, Kaczmarek LK, Jonas EA (2008) PKC-induced intracellular trafficking of Cav2 precedes its rapid recruitment to the plasma membrane. J Neurosci 28:2601-2612. CrossRef Medline 